\title{
BUSINESS DEDUCTION FOR PERSONAL LIVING EXPENSES: A UNIFORM APPROACH TO AN UNSOLVED PROBLEM
}

\author{
Daniel I. HalPerin $\dagger$
}

\section{INTRODUCTION}

All of us eat, wear clothes and occupy houses or apartments. Many of us travel, seek entertainment at country clubs, night clubs or sporting events and try to improve ourselves through education. The norm is to pay for these items out of after-tax income. A lucky few, however, get an affirmative answer to the popular question, "Is it deductible?" and pay taxes only on income left over after satisfying their needs or desires for one of more of these items. This is a major advantage for an individual in a high tax bracket. For example, if a consumption expenditure is deductible, a taxpayer in the 50 percent bracket can double his pleasure at the same out-of-pocket cost. Even if he would rather not increase his use of the deductible item, there is still a significant benefit. ${ }^{1}$

\section{A. The Problem}

The difficulty arises because

an individual is ... regarded for tax purposes as having two personalities: one is a seeker after profit who can deduct the expenses incurred in that search; the other is a creature satisfying his needs as a human and those of his family but who cannot deduct such consumption and related expenditures. ${ }^{2}$

† Associate Professor of Law, University of Pennsylvania. B.B.A. 1957, City College of New York; J.D. 1961, Harvard University. Member, New York Bar.

' For example, assume an individual decides he can afford to spend for entertainment the amount left after the tax collector takes his share of $\$ 10,000$ of income. If the tax bite is $50 \%$, there is $\$ 5000$ left for such activity, yet when entertainment is deductible, the entire $\$ 10,000$ can be spent for this purpose. If instead the entertainment expenditure were kept constant at $\$ 5000$, there would be $\$ 2500$ left from the $\$ 10,000$ originally set aside for entertainment for other purposes. That is:

Taxable income before entertainment

$\$ 10,000$

Entertainment deductible

Taxable income

Tax at $50 \%$

Excess available

$\frac{-2,500}{\$ 2,500}$

2 I S. Surrey, W. Warren, P. McDaniel \& H. Ault, Federal Income Taxation, Cases and Materials 496 (1972) [hereinafter cited as Surrey] 
In the words of the Internal Revenue Code, in determining taxable income deductions are allowed for "all the ordinary and necessary expenses paid or incurred during the taxable year in carrying on any trade or business," 3 but "no deduction shall be allowed for personal, living or family expenses." "But since the individual remains one individual, where is that dividing line?"5 That is the question this Article seeks to answer.

The Internal Revenue Service and the courts have struggled to reach a solution as to the deductibility of many kinds of expenditures with very little guidance from Congress. In the course of many years, rules of thumb have been developed; unfortunately, if there is a rationale underlying these rules, it is most often unarticulated. Furthermore, there has been little or no effort to seek uniformity in the rules governing various types of expenditures-as if the line drawn between personal and business expenditures in one area has no bearing on where it should be drawn when the issue arises in another. ${ }^{6}$ No doubt the "inadequate distinction between consumption and business expense make some inequities unavoidable." 7 Some inequities, perhaps, but must we swallow so easily the extent of unfairness that presently exists? Can we explain the failure to articulate any underlying principle to justify the rather arbitrary rules, or even to discuss how decisions in one area relate to those in another?

It is particularly interesting to contrast the apparent liberality of the treatment of travel, meals, lodging and entertainment with the strictness in the allowance of deductions for such items as education, job-seeking costs and clothing. Perhaps there is a personal benefit from a professional education at law school or medical school, or even from a cram course taken to prèpare for the qualifying examination to become a certified public accountant that justifies denying a tax deduction for these expenditures. But no one unattuned to the peculiarities of the tax law would believe that the likelihood of personal benefit from such a short

${ }^{3}$ INT. Rev. CODE of 1954, § 162.

${ }^{4}$ Id. $\$ 262$.

5 SURREY, supra note 2, at 496.

'Lee, Command Performance: The Tax Treatment of Employer Mandated Expenses, $7 \mathrm{U}$. Rich. L. REv. 1, 1 (1972). For one of the rare cases where a court sought to justify what appeared to be a distinction between two types of expenditures, see Henry C. Smith, 40 B.T.A. 1038 (1939), affd mem., 113 F.2d 114 (2d Cir. 1940) (child care compared with entertainment, traveling expenses and the cost of an actor's wardrobe).

${ }^{7} \mathrm{H}$. Simons, Personal Income Taxation 106-07 (1938). After reading Professor Simons' book one is impressed with the difficulty of undertaking the task of this Article. That author states: "There is here an essential and insuperable difficulty, even in principle." Id. 123. See also id. 53-54. 
cram course exceeds the potential personal enjoyment from viewing the Super Bowl or flying to a convention at Las Vegas. As President Kennedy stated in 1961:

Too many firms and individuals have devised means of deducting too many personal living expenses as business expenses, thereby charging a large part of their cost to the Federal Government. . . .

This is a matter of national concern, affecting not only our public revenues, our sense of fairness, and our respect for the tax system, but our moral and business practices as well. ... [T] he time has come when our tax laws should cease their encouragement of luxury spending as a charge on the Federal Treasury. . . .

... Even though in some instances entertainment and related expenses have an association with the needs of business, they nevertheless confer substantial tax-free personal benefits to the recipients. . . .

I, therefore, recommend that the cost of such business entertainment and the maintenance of entertainment facilities (such as yachts and hunting lodges) be disallowed in full as a tax deduction and that restrictions be imposed on the deductibility of . . . expenses of business trips, combined with vacations, and excessive personal living expenses incurred on business travel away from home. ${ }^{8}$

According to Secretary of the Treasury Dillon, the President's disallowance proposals were justified because: "The characteristic feature of all of these expenses is that they confer substantial personal benefits which are in large measure a substi-

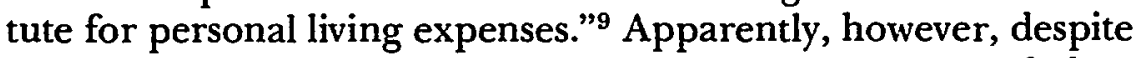
this personal consumption, it is necessary to accept a tax deduction for entertainment expenses reasonably associated with the production of income since

expenses incurred for valid business purposes should not be discouraged since such expenses serve to increase business income, which in turn produces additional tax revenues for the Treasury. If valid business expenses were to be disallowed as a deduction (particularly expenses associated with selling functions), there might be

${ }^{8}$ Hearings on Tax Recommendations of the President Contained in His Message Transmitted to Congress, April 20,1961 Before the House Comm. on Ways \& Means, 87th Cong., 1st Sess. 12-13 (1961) (emphasis added) [hereinafter cited as Hearings]. For more details of the President's proposals see notes 165, 201, 212 infra.

${ }^{9}$ Hearings, supra note 8 , at 43 . 
a substantial loss of revenue where business transactions are discouraged, or where they fail to be consummated. ${ }^{10}$

Thus, Congress responded to the President's urging that "[t]he slogan-'It's deductible" "11 should pass from our scene only by requiring a closer connection between the entertainment expenditure and the potential business advantage, ${ }^{12}$ and by insisting upon substantiation of entertainment expenditures instead of the rough approximations previously allowed under the Cohan rule. ${ }^{13}$

One is struck, however, by the failure to apply this reasoning to other expenditures which involve mixed business and personal motives. If a deduction for entertainment expenditures reasonably designed to produce income must be allowed, regardless of the accompanying personal benefit, do not similar considerations require a deduction for the less obviously personal costs of education in medicine or law, or even an undergraduate degree in such fields as business or engineering? If a businessman can assert that his taxable income would be overstated and his income-seeking behavior inhibited if he were not permitted to deduct the legitimate business-generating cost of entertaining customers, cannot the attorney who is prohibited from deducting his law school tuition or even the cost of a bar review cram course similarly state that his lifetime professional income is not as great as the tax collector is asserting?

\section{B. Summary of a Proposal}

The position that a deduction ought to be allowed for all income-generating expenses, while quite correct, is really beside the point: If such expenditures actually provide personal satisfaction, the amount of such satisfaction ought to be included in income. The fairest income tax would take account of income

${ }^{10} \mathrm{~S}$. Rep. No. 1881, 87th Cong., 2d Sess. 25 (1962), reprinted in 1962-3 Cum. Bull. 707, 731 [hereinafter cited as S. REP.].

${ }^{11}$ Hearings, supra note 8, at 13.

12 INT. REv. CODE OF 1954, § 274. As the House put it in describing its version, which was tougher than what was eventually enacted, "the taxpayer must show a greater degree of proximate relation between the expenditure and his trade or business than is required under present law." H.R. REP. No. 1447, 87th Cong., 2d Sess. 20 (1962), reprinted in 1962-3 CuM. Bull. 405, 424 [hereinafter cited as H.R. REP.]. For more details see text accompanying notes $213-23$ infra.

${ }^{13}$ Cohan v. Commissioner, 39 F.2d 540 (2d Cir. 1930). The court held that where the evidence indicated that a taxpayer had incurred deductible expenditures, but their exact amount could not be determined, the court must make "as close an approximation as it can" rather than disallow the deduction entirely. Id. at 544. 
from "whatever source derived." 14 On-the-job entertainment, traveling expenses and other expenditures which but for their connection with income-generating activities would be considered to provide personal satisfaction should not be distinguished from other forms of enjoyment.

An indirect way of taxing these benefits is to deny a deduction to the extent personal satisfaction has been obtained from the expenditure. If satisfaction were equal to cost, this approach would suggest complete disallowance. This reasoning is the foundation of this Article's conclusion in Part II that, assuming perfect information and absence of administrative problems, a deduction should be permitted only to the extent that the costs incurred exceed the personal benefit obtained. The proposal does not, therefore, represent a challenge to the right to a deduction for expenditures intended to produce income.

There are two difficult questions raised by this suggestion. First, does not such a broad approach also require the taxation of such things as leisure, personal relationships, and the prestige and other satisfactions that come from one's job? Thus, it might be argued that the pleasures from on-the-job entertainment are indistinguishable from other less tangible satisfactions many people derive from their work, and it is illogical or, worse, unfair to tax one and not the other. While it does not seem feasible to go so far, the approach suggested in this Article is not precluded by this problem. ${ }^{15}$

The second difficulty is inability to measure personal enjoyment or consumption accurately in light of the coincidence of business and personal motives. For example, if a couple goes to a restaurant for purely personal reasons and pays $\$ 25$ for dinner, it can be assumed they expect to get at least $\$ 25$ worth of personal satisfaction. However, if there is a business motive, such as the possibility of generating additional income in excess of the $\$ 25$ cost, one might well buy the meal even if it is not worth the $\$ 25$ in the form of consumption. Therefore, it is not clear how much satisfaction the dinner is producing. Moreover, since this value will vary from case to case and can be anything down to zero, it is impossible to make individualized measurements.

Despite this difficulty, the development of a theoretically correct approach does enable one to draw some conclusions

14 U.S. Const. amend. XVI; INT. Rev. CODE of 1954, § 61.

${ }^{15}$ See text accompanying notes 40-51, 70 infra. 
about the appropriateness of particular practical rules. This proposition is tested in Part IV, in which current law is analyzed in order to ascertain the extent to which it is consistent with the principle that all personal benefit should be taxed. The procedure for undertaking this analysis is developed in Part III. The approach suggested in this Article would be easiest to apply in cases in which satisfaction equals cost or is so minimal that it can be ignored. Part III suggests some factors which would tend to show the existence of either of these conditions. Moreover, it argues that it is not necessary to have complete assurance that personal satisfaction equals cost in order to make this assumption for purposes of taxation. While undoubtedly this will lead to overtaxation in some circumstances, such a result is far more acceptable than the understatement of income which results from ignoring the personal benefit. Of course, there will be many circumstances in which the matter is completely in doubt, and some sort of arbitrary allocation or partial taxation may be the best solution available. The conclusion reached by this Article, summarized in Part V, is that the law should be liberalized in the area of education and job-seeking costs, and that it should be tightened with respect to the deductibility of expenses for travel, entertainment, meals and lodging, and home offices.

\section{Some Related Matters Not Discussed Herein}

There are a number of related issues which will not be dealt with here. For the most part, no distinction will be made between those business expenses which are currently deductible and those which should be capitalized, ${ }^{16}$ since such a distinction does not raise the threshhold business-personal issue with which this Arti-

${ }^{16}$ Some cases have refused to allow education costs to be amortized, ruling that they are personal. Bernard V. Hall, $29 \mathrm{CCH}$ Tax Ct. Mem. 1363 (1970); Nathaniel A. Denman, 48 T.C. 439 (1967). See David N. Bodley, 56 T.C. 1357 (1971). It has been argued, however, that such results are explicable on the ground that the estimated useful life of the education cannot be determined. Wolfman, Professors and the "Ordinary and Necessary" Business Expense, 112 U. PA. L. REv. 1089, 1093, 1098, 1112 (1964) [hereinafter cited as Expense]. Nevertheless, while the Internal Revenue Service and the courts have been quite strict in insisting upon proof of the useful life of intangible assets such as goodwill or of contracts which are generally renewed, Treas. Reg. $\$ 1.167$ (a)-3 (1956); see B. Bittker \& L. Stone, Federal. Income Estate and Gift Taxation 329-30 (4th ed. 1972), it would seem that the length of the period over which education will be useful in the business can be estimated with reasonable accuracy based upon life expectancy or normal retirement age. Thus, in a closely analogous situation, a fee paid by a physician to a hospital in exchange for a nontransferable lifetime privilege to use the hospital's facilities has been held to be amortizable over the physician's life expectancy. Glenn $\mathbf{L}$. Heigerick, 45 T.C. 475 (1966); Rev. Rul. 70-171, 1970-1 Cum. BuLl. 55. See Wolfman, The Cost of Education and the Federal Income Tax, 42 F.R.D. 535, 547-48 (1966) [hereinafter cited as Education]. See text accompanying notes 95-97 infra. 
cle is concerned. There is also no treatment of commuting and child-care expenses. The nondeductibility of these expenditures is probably not caused by any doubt that these expenses are business related, but by the belief that they are based on underlying personal decisions which give rise to personal satisfaction. Thus, what makes commuting costs nondeductible is the assumption that they are caused by the personal decision to live in the suburbs and not within walking distance of work. ${ }^{17}$ Similarly, the necessity of incurring child-care expenses is dependent, at least in some circumstances, on an initial personal choice to have children. ${ }^{18}$ This Article, in contrast, focuses on the personal satisfaction derived from the expenditure itself. Additionally, it is impossible to discuss the deductibility of child-care expenditures without considering such policy issues as whether the bearing of children and the employment of married women should be encouraged. These aspects of the problem are inconsistent with the focus of this Article ${ }^{19}$ upon the allowance of deductions under principles which seek only an accurate determination of net income.

${ }^{17}$ See generally Bittker, $A$ "Comprehensive Tax Base" as a Goal of Income Tax Reform, 80 HARv. L. REv. 925, 953 n.46 (1967). The constant refrain that the cost of commuting to work is not deductible, Treas. Reg. \$\$ 1.162-2(e) (1958), 1.212-1(f) (1957), 1.262-1(b)(5) (1958), is broken by an allowance of the cost of transporting tools where the taxpayer commutes by automobile only because of the heavy load, Rev. Rul. 63-100, 1963-I CuM. BulL. 34; see Fausner v. Commissioner, 413 U.S. 838 (1973). The suggested rationale for denying the deductibility of the expense of commuting does not support this concession. If the taxpayer lived next door to the job, it would not be very expensive to transport the tools. The necessity to drive further than this with the tools is a result of personal choice.

However, if it were possible to examine each individual decision to determine if there was actually an opportunity to live closer, it would be proper to permit commuting deductions. See Wright v. Hartsell, 305 F.2d 221 (9th Cir. 1962); Klein, Income Taxation and Commuting Expenses: Tax Policy and the Need for Nonsimplistic Analysis of "Simple" Problems, 54 CoRnell L. Rev. 871 (1969). Professor Klein reasonably suggests that a taxpayer who would be allowed a deduction for the cost of meals and lodging because, for example, he obtained a temporary job away from his normal place of work, should be allowed to deduct the cost of commuting, if instead of living apart from his family he chose to travel the extra distance daily or several times per week. There are indications the Commissioner agrees. See Rev. Rul. 190, 1953-2 Cum. Burl. 303. More controversial is Professor Klein's tentative suggestion that low income people could well be allowed to deduct the cost of commuting, because their choice of residence is likely to be severely restricted and their only real decision is where to work. These people did not make a personal choice to live far from the job.

${ }^{18}$ Klein, Tax Deductions for Family Care Expenses, 14 B.C. IND. \& Comm. L. Rev. 917 (1973). Even if one were to conclude that the decision to have children is not the kind of personal decision which will shut off the possibility of a deduction, baby-sitting can still be rejected as a business expense on the analysis that, at least under some circumstances, the purely personal benefits obtained from having a baby-sitter for the children are well worth the costs incurred.

${ }_{19}$ These questions also have been adequately treated elsewhere. See Feld, Deductibility of Expenses for Child Care and Household Services: New Section 214, 27 TAx L. REv. 415 (1972); Hjorth, A Tax Subsidy for Child Care: Sec. 210 of the Internal Revenue Act of 1971, 50 TAXES 133 (1972); Klein, supra note 18. See also Blumberg, Sexism in the Code: A Comparative Study of Income Taxation of Working Wives and Mothers, 21 Buffalo L. Rev. 49 (1971) (written prior to the 1971 changes). 


\section{The Theoretically Correct Result}

In order to test the hypothesis that personal satisfaction should not escape inclusion in income merely because it is obtained in the course of business, it is useful to develop the set of circumstances in which the issue discussed in this paper may arise, and to evaluate the acceptability under these conditions of the rules which are now being used or which may be suggested. In order to make the illustrations more forceful, hypothetical taxpayers named in accordance with the relative strengths of their business and personal interests will be described. The taxpayer could be motivated solely by either business (All Business) or personal (Solely Pleasure) considerations. In other cases both reasons would be present, but only one would be sufficiently strong to justify the act by itself (Enough Business or Sufficient Pleasure). In still other situations both the personal and business value would be great enough even if the other did not exist (Either Alone). It is also possible that neither reason alone would be sufficient, but in combination they provide enough impetus (Neither Alone).

The motivations of these six taxpayers will be described in greater detail, after which their entitlement to a deduction under several possible tests will be discussed. These tests can be briefly described as follows:

1. Business Benefit-A deduction would be allowed to the extent of the amount that would have been spent solely for business purposes.

2. Lack of Consumption-A deduction would be allowed only to the extent the expenditure exceeds the amount that would have been spent for personal satisfaction.

3. Motivation-A deduction would be allowed:

a) If the principal purpose of the expenditure was business.

b) Only if the expenditure would have been made regardless of personal reasons.

c) If the expenditure would not have been made in the absence of business reasons.

4. Allocation-A partial deduction would be allowed, equal to the ratio of the amount that would have been spent for business purposes to the total of the business and personal values. 


\section{A. Some Examples}

As stated above, the possibilities as to the mixture of business and personal motivations for certain behavior can best be examined by presenting six individuals, All Business, Enough Business, Neither Alone, Either Alone, Sufficient Pleasure and Solely Pleasure, each of whom have the opportunity to purchase two tickets to a local professional football game for $\$ 25 .{ }^{20}$ They each decide to go to the game and take along Mr. $X . X$ is a neighbor, who also happens to work for a company which is a potential buyer of the product manufactured by the business individually owned by the particular taxpayer. In order to demonstrate that the issues are the same with respect to different types of expenditures, the same six individuals will also be examined as they face a choice between college and an immediate business career.

All Business hates football, and would not ordinarily buy a ticket to a game even if one were available for $\$ 1$ or even, $1 \not x$. In fact, even if he enjoyed football, he finds it so distasteful to be with $X$ that in the absence of business considerations, he would not pay anything for any entertainment if he had to be in $X$ 's presence to take advantage of it. However, All knows how much $X$ loves football, and that he has been wanting to go to this particular game. He figures the investment of $\$ 25$ and his time is well worth it in view of the potential business $X$ can throw his way.

All Business hates to study, and expects no personal enjoyment or benefit from college. However, when he considers his prospects for employment, he decides that in terms of the likely increase in his earning power, the money required for a college degree is well worth it.

Enough Business also calculates that the potential business he can obtain through $X$ is well worth the $\$ 25$ expenditure on the football tickets. Aside from these considerations, Enough does not get sufficient enjoyment from football to spend $\$ 25$ for two tickets. However, he would as a purely personal matter jump at the chance to go to the game if the two tickets were available for $\$ 10$.

Enough Business comes to the same conclusion as All Busi-

${ }^{20}$ This approach was suggested by Professor Klein's article on travel expenses, which discusses counterparts of at least Neither Alone and Either Alone. Klein, The Deductibility of Transportation Expenses of a Combination Business and Pleasure Trip-A Conceptual Analysis, 18 Stan. L. Rev. 1099 (1966). 
ness concerning the economic value of a college degree. However, unlike All he expects some personal enjoyment and benefit which, while not equal to the full cost of a college education, is worth something to him. Thus, Enough Business is one who expects some personal enjoyment, although less than full cost, but who values the business benefit enough to act for this reason alone.

Neither Alone assumes that there is some chance that taking $X$ to the football game will improve his opportunity of obtaining business from $X$ 's employer, but while he would spend something for this possibility, it is not worth the required $\$ 25$ outlay. On the other hand, while Neither likes football and enjoys the company of his neighbor $X$, from the purely personal standpoint he would not spend $\$ 25$ for the tickets. Nevertheless, when Neither Alone adds together the amount of enjoyment he expects and the business potential, he decides that the tickets are worth $\$ 25$.

Neither Alone is not much for studies but most of his friends and family have gone or are contemplating going to college, and he suspects his future personal relationships will be hampered by the absence of a college education. However, when he thinks of the cost of a college education in terms of time and money, Neither thinks that he will risk this hindrance. Yet, when it comes to looking for work, Neither Alone finds that the things he wants to do all require a college degree. Even though evidence would indicate that the present value of Neither's increased earnings potential through the college degree is in excess of the cost of the college education, Neither is not that farsighted and he is thinking of settling for a lesser job rather than facing four years of college. However, after long thought, Neither determines that the combined personal and job benefits are worth the investment in time and money. Thus, in Neither's case personal and business values could each range from minor amounts to almost, although not quite, enough to justify the expenditure for one of the reasons alone, but the sum of the two values is at least equal to market.

Either Alone, like All and Enough Business, thinks that taking $X$ to a game will soften him up substantially, and that the $\$ 25$ expenditure will be a cheap way to gain additional business. Unlike All and Enough, however, Either Alone is a great lover of football and enjoys $X$ 's company immensely. Therefore, he would have bought the tickets and taken $X$ to the game even if $X$ worked in a wholly unrelated field. 
Either Alone thinks college is worth the time and tuition both for the personal satisfaction to be obtained and for the effect it would have on his potential income. In sum, Either Alone expects sufficient personal satisfaction to act in the absence of business motives, but he also expects enough of a return to justify the expenditure even if personal satisfaction were not a factor.

Sufficient Pleasure is similar to Either Alone in his love for football and his friendship for $X$; he would buy the tickets for purely personal reasons. He does think that there is some chance he will gain business as a result of the day's activities, but he would not pay $\$ 25$ for this possibility.

Sufficient Pleasure wants to go to college to improve his mind. Perhaps it will improve his economic potential but Sufficient, who really expects to go into his father's business, doesn't think much of that aspect, although he would pay some part of the tuition to achieve this end. Thus, Sufficient Pleasure is one who expects some business return although not enough to justify the full expenditure, but who expects enough personal satisfaction to act for this reason alone.

Solely Pleasure is similar to Either Alone and Sufficient Pleasure in his love for football and in his enjoyment of $X$ 's company. Solely thinks that there is little or no chance he will gain any business by the effort, and from the business point of view, does not think that any expenditure is justified.

Solely Pleasure thinks of himself as a potential artisan. He is convinced going to college will not increase his earning potential at all, but decides to go because of the personal benefits. In short, Solely acts only for personal satisfaction and takes no account of business factors.

\section{B. Possible Tests}

Given this range of factual situations, who among the six individuals is entitled to a full or partial deduction for the cost of the football tickets or the college education? At least four possible approaches to this question can be suggested.

\section{Business Benefit}

The focus could be on the relationship of the activity to the taxpayer's business. ${ }^{21}$ Under this approach, a deduction would

${ }^{21}$ See Wolfman, Education, supra note 16 , at 547-49. 
be allowed for the amount that the taxpayer would have spent for business purposes. As discussed above, the committee report issued in connection with the 1962 amendments with respect to the deduction of entertainment expenses is in accord with this approach. ${ }^{22}$

Given the requisite connection, an expenditure would be deductible under this rule even if it would have been made in the absence of a business motive, or even if the primary motivation were personal. Thus, under this test, Either Alone would be entitled to a full deduction as well as All and Enough Business; Neither Alone and Sufficient Pleasure would be entitled to a partial deduction of up to $\$ 24.99$ for the $\$ 25$ football tickets, depending upon the amount they would be willing to spend for business purposes.

\section{Lack of Consumption}

Taking the cue from section 262 of the Internal Revenue Code, which provides that no deduction shall be allowed for personal, living and family expenses, a deduction could be denied to the extent that the individual derives a personal benefit from the transaction. The tax treatment of college and professional education is consistent with a belief that a deduction should be disallowed whenever there seems to be a reasonable possibility of personal satisfaction.

Personal satisfaction should be measured by that amount not in excess of the market price which a person would be willing to pay in the absence of business considerations, and not by an attempted measurement of actual enjoyment. Thus, someone might possibly derive $\$ 1,000$ of enjoyment from a vacation that costs $\$ 500$ in the sense that if asked after, or even before, a trip what he would pay for it, he would say $\$ 1,000$. Yet satisfaction in excess of the amount paid would not be deemed to be income. Nor would a loss be permitted if he got only $\$ 200$ worth of vacation for the $\$ 500$ expenditure. Thus, the amount that would have been paid seems the crucial measure of satisfaction. ${ }^{23}$

Under this approach, only All Business would get a full deduction. Either Alone, Sufficient Pleasure and Solely Pleasure,

${ }^{22}$ See text accompanying note 10 supra.

${ }^{23} \mathrm{H}$. SimoNs, supra note 7 , at 53,120 . The economist refers to the excess of personal valuation over market price as consumer surplus. P. SAMUELSON, ECONOMICS 436-38 (9th ed. 1973). For an explanation of this term, see Aaron, What is a Comprehensive Tax Base Anyway?, 22 NATL TAX J. 543, 548-49 (1969). The casualty loss deduction, INT. Rev. CODE of 1954, § 165(c)(3), may suggest, however, that actual enjoyment is in some cases relevant to taxability. 
who obtain satisfaction to the extent of cost, would not be entitled to any deduction. Note in particular the dramatic difference for Either Alone, who is allowed a full deduction under the business benefit approach and none under this approach.

In the case of Enough Business and Neither Alone, the personal benefit is less than the costs involved, and some deduction seems justified. Depending on the particular circumstances, this could range from almost the entire $\$ 25$ cost of the football tickets to as little as a penny.

\section{Motivation}

A third approach would consider the taxpayer's motivation. ${ }^{24}$ There are various ways a purpose test could be stated.

\section{a. Principal Purpose}

A deduction could be permitted only if the business reason was the principal purpose of the transaction. ${ }^{25}$ Under this approach, All and Enough Business would be entitled to a deduction while Sufficient and Solely Pleasure would not, since the primary motivation of the last two is clearly personal. Insufficient facts are given to make this determination in the case of Neither Alone or Either Alone, and it is likely that Neither and Either themselves would not know which factor is the most important.

To further illustrate Either's situation, assume the current rent for an eight room house is $\$ 480$ per month, or $\$ 60$ per room. Either Alone determines to rent such a house in lieu of a seven room house he was considering at $\$ 420$ per month. Either, an attorney, brings work from the office occasionally and uses the extra room as an office and also as a guest room. Even if Either Alone did not work at home, he would have wanted the eighth room because of the frequency with which he has overnight guests. Similarly, the office use is so important to him that he would have acquired the eighth room solely for this purpose. Use of the eighth room for these two purposes can be carried out without their interfering with each other.

It is assumed that Either Alone would spend at least the extra $\$ 60$ for a guest room or for a home office, even if each

${ }^{24} \mathrm{H}$. Simons, supra note 7 , at 54 .

${ }^{25}$ See text accompanying notes 55, 153-55, 210 infra; Leonard F. Cremona, 58 T.C. 219, 223 (1972) (Tannenwald, J., concurring); R. GoOdE, The Individual Income TAX 98 (1964); McNulty, Tax Policy and Tuition Credit Legislation: Federal Income Tax Allowances for Personal Costs of Higher Education, 61 CAL. L. REv. 1, 28 (1973). 
reason existed independently of the other. In order to ascertain which purpose is more important, it is necessary to isolate each purpose and ask how much Either would be willing to spend for the eighth room. If he stops at $\$ 60$ for the guest room but states that the office is worth $\$ 70$, then his principal purpose is business and the deduction would be allowed. If the opposite were true, the deduction would be disallowed.

Turning now to Neither Alone, assume he is offered a job in Phoenix for $\$ 1,000$ a year more than he is earning in New York. The extra income alone does not seem to. justify a move, but Neither, having visited Phoenix, is convinced that he would like to live there. While he did not think of moving in the absence of this job offer, the combination of the extra money and the inviting climate is enough to induce Neither to move. If it is assumed that the cost of a move to Phoenix is $\$ 5,000$, it is clear that the sum of the business and personal gain is at least $\$ 5,000$. However, while the maximum and minimum valuation of either could be $\$ 4,999^{\circ}$ or $\$ 1$, respectively, the effectuation of the predominant purpose, if there was one, must be valued by Neither Alone in excess of $\$ 2,500$. If one could determine that the additional income would cause Neither Alone to spend $\$ 3,000$ to move to Phoenix, while he values the advantage in climate at only $\$ 2,750$, then the principal purpose test would suggest that the full $\$ 5,000$ of moving costs should be deductible.

\section{b. Business Reasons Sufficient}

A deduction could be allowed whenever business reasons alone would have caused the transaction to take place. This approach, like the business benefit approach first discussed, permits a deduction for All and Enough Business and Either Alone, who had sufficient business reasons for going to the football game or attending college. However, unlike the business benefit approach, it would not sanction a partial deduction for Neither Alone or Sufficient Pleasure.

\section{c. Business Reasons Necessary}

A deduction could be permitted whenever business is a motivating factor in the sense that personal reasons alone would not cause the transaction to take place. This approach is closely related to the lack of consumption test and results in a deduction for All and Enough Business and Neither Alone, who would not have gone to the football game or college in the absence of 
business reasons. Either Alone and the Pleasures achieve enough personal satisfaction to justify the transaction in any event and would be denied a deduction.

\section{Allocation}

Recognition that both business and personal interests are involved could suggest a fourth approach; namely, allocation based on the relative value of each. Thus, if the personal value of an activity were known to be $\$ 5,000$, while the business value was $\$ 10,000$, a deduction for two thirds of the cost, whatever it might be, could be allowed. Alternatively, even if one could not quantify the separate valuations, it would still be possible to proceed on this basis if the relationship of the valuations were somehow known, or there were a willingness to "guesstimate."

This method would explain section 274(c) of the Internal Revenue Code, which under certain circumstances requires an allocation of the cost of foreign travel based upon the number of days devoted to business as compared to the total elapsed time of the trip. The assumption appears to be that a comparison of the number of days spent on each gives a fair approximation of the relative business and personal valuations. ${ }^{26}$

\section{Summary of Results}

The results under the various rules suggested above may be summarized in the following chart:

\begin{tabular}{lcccccc}
\hline & $\begin{array}{c}\text { All } \\
\text { Business }\end{array}$ & $\begin{array}{c}\text { Enough } \\
\text { Business }\end{array}$ & $\begin{array}{c}\text { Neither } \\
\text { Alone }\end{array}$ & $\begin{array}{c}\text { Either } \\
\text { Alone }\end{array}$ & $\begin{array}{c}\text { Sufficient } \\
\text { Pleasure }\end{array}$ & $\begin{array}{c}\text { Solely } \\
\text { Pleasure }\end{array}$ \\
\hline $\begin{array}{c}\text { Business bene- } \\
\text { fit }\end{array}$ & Yes & Yes & Part & Yes & Part & No \\
$\begin{array}{c}\text { Business rea- } \\
\text { sons suffi- } \\
\text { cient }\end{array}$ & Yes & Yes & No & Yes & No & No \\
$\begin{array}{c}\text { Lack of con- } \\
\text { sumption }\end{array}$ & Yes & Part & Part & No & No & No \\
$\begin{array}{c}\text { Business rea- } \\
\text { sons neces- } \\
\text { sary }\end{array}$ & Yes & Yes & Yes & No & No & No \\
$\begin{array}{c}\text { Principal pur- } \\
\text { pose }\end{array}$ & Yes & Yes & Maybe & Maybe & No & No \\
Allocation & Yes & Part & Part & Part & Part & No \\
\hline
\end{tabular}

The chart indicates that the Alones ${ }^{27}$ are subject to the most

${ }^{26}$ See Klein, supra note 20 . For a detailed discussion of allocation of travel expenses see text accompanying notes 165-69, 183 infra.

${ }_{27}$ As has been noted, however, the valuational differences between Enough Business 
conflicting results, and it may be useful to highlight these differences in the search for the correct rule.

Suppose that the cost of college tuition is $\$ 10,000$. Neither Alone thinks that it is worth $\$ 7,000$ from a business standpoint, and that he would pay $\$ 4,000$ to make himself a more interesting person. The resulting deductions are shown in the chart below. If the student were Either Alone, and he had decided that college was worth $\$ 10,000$ from either the personal or business standpoint, as the chart indicates, the business benefit approach allows a full deduction and the consumption approach permits no deduction. The principal purpose route could go either way. An allocation based upon relative values of each would, assuming relatively equal valuations, allow a deduction for about fifty percent of the cost.

Deduction Allowed

\begin{tabular}{lrr}
\hline Approach & Neither & Either \\
\hline Business benefit & $\$ 7,000$ & $\$ 10,000$ \\
Business reasons sufficient & 0 & 10,000 \\
Lack of consumption & 6,000 & 0 \\
Business reasons necessary & 10,000 & 0 \\
Principal purpose & 10,000 & $?$ \\
Allocation & 6,364 & 5,000 \\
\hline
\end{tabular}

\section{Resolving the Conflict}

Reliance on motivation to determine whether an expenditure will be deducted in full or not at all will produce extremely arbitrary results. The primary purpose test could, in the case of Neither Alone, allow a $\$ 10,000$ deduction for the cost of education even though business considerations would cause him to spend only $\$ 7,000$. On the other hand, if the situation were reversed and Neither Alone would spend $\$ 7,000$ for personal satisfaction and $\$ 4,000$ to produce income, a deduction would be denied even though there was some business benefit and consumption did not equal the full outlay. In the case of Either Alone, who has both a personal and business valuation at least equal to cost, it would be necessary to determine how much more

or Sufficient Pleasure and the Alones may be slight. For example, if an activity costs $\$ 100$, they may value it as follows:

Business Value

Personal Value

Category

\begin{tabular}{ccl}
\hline 100 & 99 & Enough Business \\
99 & 99 & Neither Alone \\
100 & 100 & Either Alone \\
99 & 100 & Sufficient Pleasure \\
\hline
\end{tabular}


than cost he would be willing to spend for either purpose and, depending on the result, to allow the entire amount to be deducted or none at all. These results are hard to defend.

If a deduction were allowed only when business reasons alone would cause the expenditure in question, Neither Alone, despite a business motive which would cause him to spend $\$ 7,000$ on education, would get no deduction because he would not have gone to college unless he also sought personal satisfaction. Since Neither Alone might spend as much as $\$ 9,999$ for business reasons, it can be seen that this test also can be arbitrary.

Allowance of a full deduction whenever business is a necessary factor denies a deduction to Either Alone, who would spend $\$ 10,000$ for business purposes, but grants Neither Alone a full $\$ 10,000$ deduction despite the fact that he would only spend $\$ 7,000$ in the pursuit of income. Since Neither's personal valuation could be as high as $\$ 9,999$, the allowance of a full deduction whenever business is a motivating factor is again likely to be highly arbitrary and could even produce a full deduction when business reasons played a very minor role.

As should be clear, the last-mentioned rule would allow a business deduction for any expenditure that would not have been made for personal reasons alone. Thus, if a person would not go to a night club at regular prices in the absence of business reasons, he would, if he went in connection with business, get a deduction for the full cost. If he would not eat at a restaurant for personal reasons alone, he could deduct the full cost of the meal, or at least the excess over what it would cost to eat at home. The difficulty with this approach it that it ignores the consumption which has occurred. The fact that someone would not spend \$20 to eat dinner in a good restaurant does not mean that he attaches no personal satisfaction to the meal. It just means that its personal value is less than the market price and therefore he spends his money in other ways. He may very well be willing to purchase the meal for $\$ 10, \$ 15$ or even $\$ 19.99$.

It is evident that examination of whether business or personal reasons are a motivating, or the principal motivating, factor cannot lead one to a logical answer, at least in an unreal world in which all valuations can be accurately measured. A test based on motivation must, if it is logical at all, represent an attempt to approximate more reasonable results. ${ }^{28}$ However, the analysis so far presented does not enable one to choose between the remaining approaches.

\footnotetext{
${ }^{28}$ Compare Klein, supra note 20 , at 1109 , with sources cited note 25 supra.
} 
It seems correct to allow a deduction for an expenditure which is intended to produce income. On the other hand, there is a clear admonition against a deduction for personal living expenses or the enjoyment of consumption out of pre-tax dollars. Thus, either approach is logical, at least on its face. Is there actually a conflict? Should an allocation approach be used as a compromise between two equally correct solutions? Or can a solution be derived from an examination of the fundamental purpose and proper form of the income tax?

\section{E. A Suggested Approach}

\section{The Definition of Income}

Under the widely accepted Haig-Simons analysis, income is defined as "the algebraic sum of (1) the market value of rights exercised in consumption and (2) the change in the value of the store of property rights between the beginning and end of the period in question." 29 More simply, this may be expressed as the sum of personal consumption plus increase in individual net worth.

Treatment of all forms of income alike, as the Simons formulation suggests, contributes to the fairness of the tax law by treating similarly people in approximately the same economic circumstances (horizontal equity), and by fairly distributing the cost of the government among income classes (vertical equity). ${ }^{30}$ It also avoids the distortion in the use and allocation of resources which arises if certain forms of income receive preferential treatment. ${ }^{31}$ As Professor Andrews has stated, Simons' emphasis on consumption tells us that the key to income measurement is the taxpayer's participation in the distribution of goods and services, not his contribution to the production of such goods. ${ }^{32}$

In the present context, this suggests that someone who has enjoyed travel and entertainment, albeit in connection with his job, has participated in the distribution sector and should be subject to taxation. One could object to the taxation of such on-the-job benefits on the ground that the arrangements could be made solely out of the desire to produce income, with no

${ }^{29}$ H. Simons, supra note 7 , at 50 .

30 J. Pechman, Federal Tax Policy 5, 67 (rev. ed. 1971).

31 Id. 67. (1972).

32 Andrews, Personal Deductions in an Ideal Income Tax, 86 HARv. L. REv. 309, 324 
interest in providing personal satisfaction to the employee. But under our tax system, as a general rule, the manner in which one has obtained property does not affect taxability. ${ }^{33}$ Thus, $\$ 1,000$ found on the street or in the drawer of an old desk purchased at an auction for $\$ 50$ is taxable. ${ }^{34}$ The motivation of the person who lost the cash is irrelevant. ${ }^{35}$

Moreover, it seems clear that the employer's motive is always to produce income and only incidentally to benefit the employee. Thus, an employer pays a salary of $\$ 5,000, \$ 10,000$ or $\$ 50,000$ a year because that is the amount considered necessary to attract a particular employee and keep him working in a productive manner. Yet the salary, of course, is income. The same can be said for benefits in kind. As Professor Bittker put it: "[t]he benefit to the employee is no less real because it is a by-product of the employer's requirements." 36

The salary will not be effective, of course, unless the employee desires it. The other on-the-job benefits discussed above are distinguishable in that the employer's aim can be satisfied even though the employee gets no personal benefit. ${ }^{37}$ For example, an employer could determine that Jones would be a more valuable employee if he took some courses leading to a college degree. Although Jones may be indifferent to the personal benefits of college, the employer may still get his money's worth.

${ }^{33}$ Commissioner v. Glenshaw Glass Co., 348 U.S. 426 (1955).

${ }^{34}$ Cesarini v. United States, 296 F. Supp. 3 (N.D. Ohio 1969), affd, 428 F.2d 812 (6th Cir. 1970); Treas. Reg. \& 1.61-14 (1957); Rev. Rul. 61, 1953-1 Cum. Bull. 17. See Comment, Taxation of Found Property and Other Windfalls, 20 U. CHI. L. REv. 748 (1953).

${ }^{35}$ The payor's motivation is important in determining whether a particular transfer is a gift and if so not taxable as income. Commissioner v. Duberstein, 363 U.S. 278 (1960). The reasons for this approach are unclear. Perhaps a gift from father to son or husband to wife should be considered a sharing of income earned by the husband rather than a transfer. R. Goode, supra note 25, at 101 . Perhaps it is felt to be more efficient to deal with gifts under a gift or inheritance tax which does not create the potential problem which existts under an income tax if an unusually large amount of income is received in one year. These considerations would not apply to the taxation of fringe benefits in kind. In any event, it would seem clear that even gifts outside the family unit, at least if made in a business context, should be taxable income under an income tax. See 3 RePORT of the Royal Commission on TAXation (Canada) 465 (1966) [hereinafter cited as Carter REPORT].

${ }^{36}$ Bittker, The Individual as Wage Earner, N.Y.U. 11Th INST. ON FED. TAX. 1147, 1156 (1953). See Joseph L. Doran, 21 T.C. 374, 376 (1953).

${ }^{37}$ Of course, it might not always be so obvious that the employee's personal valuation is irrelevant to the employer's aim. Thus assume Swinger is a salesman who has an expense account which enables him to entertain customers at night clubs and theaters. Perhaps the employer's aim is met if the customer has a good time regardless of how Swinger values the free food, drink and entertainment. On the other hand, the opportunity to participate in these activities may influence the size of Swinger's compensation package. If Swinger likes it, he could probably be hired at a lower salary. On the other hand, if he dislikes the entertaining he might insist on an extra payment in the nature of combat pay. See text accompanying note 67 infra. 
This would not be true if Jones were indifferent to a raise in salary. Thus employer motivation, or the circumstances which cause the benefit to be supplied, are relevant, but only for whatever bearing they may have on the actual satisfaction obtained by the employee. If the value of the benefit to the employee is known, it should be taxable.

\section{Inclusion of On-the-Job Benefits in Income}

Taxation of employees for compensation paid in cash or in kind, or on the benefits from on-the-job entertainment does not, of course, prevent the employer from deducting the cost as a business expense. Certainly, a deduction should be allowed for any expenditure designed to produce income despite the taxable income incurred by a third person who gets personal satisfaction from it. Recognition of the possibility, of the simultaneous existence of a business expense and personal satisfaction indicates that, by concentrating on the situation of the self-employed individual who is both the provider and the recipient of the personal benefit, we have been asking the wrong question.

The business-benefit approach, allowing a full deduction to All and Enough Business and Either Alone, and a partial deduction to Neither Alone and Sufficient Pleasure, is clearly correct. Like the employer, the self-employed should get a deduction for expenses incurred in business. ${ }^{38}$ But this does not entirely dispose of the problem. All of these individuals but All Business have also enjoyed personal satisfaction. If the description of the ideal income tax outlined above is accepted, this consumption should be taxable. If the same person who is entitled to the business expense also enjoys the personal benefit, as is the case with the six self-employed individuals, the personal income could be recognized, in effect, by reducing the deductible expense otherwise allowable.

The result would be the same as under the second suggested approach, namely, that a business deduction would be allowed only to the extent that an expenditure exceeds the personal benefit enjoyed..$^{39}$ Thus, All Business is allowed a full deduction; Enough Business and Neither Alone are permitted a partial

${ }^{38}$ Thus, if this were the only dimension to the problem, it would not be upsetting that by allowing a tax deduction the government pays approximately half the cost of corporate entertainment- - or even corporate lobbying or fines. After all, the government gets one-half the income. See generally Cooper, The Tax Treatment of Business Grass Roots Lobbying: Defining and Attaining the Public Policy Objectives, 68 Colum. L. Rev. 801 (1968).

${ }^{39}$ See W. Popkin, The Deduction for Business Expenses and Losses 17 (Harvard International Tax Program Tax Technique Handbook 1973); Andrews, supra note 32, at 381 ; Klein, supra note 18 , at 934 n.91. 
deduction; and Either Alone and the Pleasures are denied any deduction. If the tax were based on consumption it would be easy to include in the tax base the amount that each of the six individuals would have been willing to spend to obtain personal satisfaction. However, under an income tax, cash compensation is taken into account when earned and should not be counted a second time when it is used for consumption. Thus, when Solely Pleasure goes to a football game for purely personal reasons his tax picture is not affected because he buys the tickets with tax-paid dollars. On the other hand, if a business deduction is claimed, pre-tax dollars are used and, if the personal benefit derived from the deducted amount is to be included in the tax base, it must be specifically accounted for. This can easily be done in the cases of All Business, Enough Business and Either Alone. Since all of them place the business benefit of the football tickets at the full cost of $\$ 25$, they are initially entitled to a $\$ 25$ deduction. For All, who is acting solely for business reasons, the matter rests at that point. Either Alone placed a personal valuation on the football tickets at an amount equal to full cost. Thus, he has received income equal to the amount of the deduction. The result is a wash and no deduction. Enough falls somewhere in between. If, for example, he places a personal value on the tickets equal to twenty percent of their cost, he should have income in that amount, leaving a net deduction of 80 percent or the excess of cost over consumption.

The explanation as to Neither Alone or Sufficient Pleasure is a bit more complex. Since they value the business benefit at less than full cost, they are entitled to a deduction for only a portion of their expenditure. Assume that Sufficient believes that the business potential would justify twenty percent of the cost of the football tickets or $\$ 5$. This amount should be deductible. The personal value of the football tickets for Sufficient was $\$ 25$. However, of this amount only $\$ 5$ came out of the business; the rest was spent from personal tax-paid funds. The result is a $\$ 5$ deduction and $\$ 5$ in income, or a wash, and no deduction.

If Neither Alone would have spent $\$ 15$ on the football tickets for business purposes, he is initially entitled to a $\$ 15$ deduction. Any personal satisfaction up to $\$ 10$ is derived from tax-paid dollars and need not be taken into account again. However, if he would have spent $\$ 20$ for personal purposes, $\$ 10$ worth of pleasure is coming from the deducted amount and should be taken into account by reducing the deduction to $\$ 5$. The result is a deduction for the excess (\$5) of the amount spent 
$(\$ 25)$ over the personal value attached to the expenditure $(\$ 20)$. Thus, as stated above, this is the net deduction in all circumstances for the Businesses, the Alones and the Pleasures.

Recognition that denial of a deduction does not result from a feeling that there has not been a legitimate expenditure for business purposes, nor even from disallowance of the business deduction, makes it easier to explain some otherwise troublesome results. This analysis would indicate that it would be proper to deny a deduction for education essential to the job or for entertainment which results in increased income, as long as the personal satisfaction was also strong enough to justify the cost.

Acceptance of this approach, however, should not cause one immediately to draft a proposed amendment incorporating it into the Internal Revenue Code. As has been noted, the items under discussion are a problem precisely because it cannot be assumed that the personal valuation attached to an expenditure is equal to its market value. Each person's valuation is different; it could be anywhere from zero up to one hundred percent of market. The proposal advanced here, if literally applied, requires knowledge of individual personal valuations which differ from person to person and of which the individual himself would not be aware in many cases. This is just not administratively feasible. Therefore, the analysis represents only a goal to guide the development of practical rules. Parts III and IV of this Article will attempt to develop such rules.

\section{F. Drawing the Line}

It may be argued that the foregoing analysis suggests that the personal satisfaction from the following aspects of one's work should be taxable, as well:

1. Any personal valuation attached by an individual to the physical nature of the job site. Thus, an individual may very well prefer to work for $\$ 100$ per week in a factory which is air conditioned and which has good lighting, as opposed to a job for $\$ 110$ a week in a factory without these amenities. At a higher income level, the executive's salary is undoubtedly affected by the luxury of the office furnishings or the company car made available to him.

2. Any personal valuation attached by an individual to the income-producing activity itself, as op- 
posed to the intermediate activities designed to help in the production of income which have been discussed. For example:

(a) the theater critic who likes watching plays;

(b) the law teacher who likes teaching class;

(c) the lawyer who enjoys arguing cases.

3. The prestige and other psychic benefits derived by an individual from a particular position.

If psychic benefits are as much consumption as entertainment is, inability to tax the former may suggest to some that one should not seek to tax the latter. ${ }^{40}$ One ground for this conclusion would be a belief that the sum of the various kinds of noncash benefits directly associated with a job is likely to be proportionally distributed among all workers, making a tax on cash roughly equivalent to a tax at a lower rate on the total satisfaction. However, it seems more likely that prestige and other psychic benefits would accompany higher-paying jobs that provide other nontaxable fringe benefits as opposed to those which yield compensation solely in cash. ${ }^{41}$ It may also be suggested that the failure to tax some fringe benefits compensates in some measure for the lack of a tax on leisure ${ }^{42}$ and for the enormous favoritism of property income over earned income which is a feature of our tax law. ${ }^{43}$ It seems unreasonable to make compensation to workers for the failure to tax leisure depend upon the amount of in-kind benefits they receive. If accommodation is necessary, it should be done more directly. Again, those benefitting most from tax-free travel and entertainment are likely to be the higher paid, who may also enjoy the tax advantages of capital gains or tax shelters. However, this may be a reason to be less concerned with a loophole likely to benefit the less well-off, such as the tax treatment of uniforms.

Thus, the proposal advanced in this Article, that the income base should be expanded to include a greater amount of travel and entertainment, can be adopted without deciding whether

40 "There is hardly more reason for imputing additional income to the [king's aide] on account of his luxurious wardrobe than for bringing into account the prestige and social distinction of a (German) university professor." H. Simons, supra note 7, at 53. See Rudolph v. United States, 370 U.S. 269, 279 (1962) (Douglas, J.. dissenting).

${ }^{41}$ Times may have changed. In 1938 Henry Simons wrote that "Compensation in kind will ordinarily be small and confined largely to people at the bottom of the income scale." H. SimoNs, supra note 7 , at 124 .

42 Simons suggested that exclusion of imputed income from services performed in the household could be justified in part by the fact that leisure income is not included within the tax base. The amount of services performed in the home would affect the available leisure time. Id. 113.

${ }^{43}$ See McNulty, supra note 25, at 17. 
further expansion of the tax base is desirable or feasible. Nevertheless, for those who feel uncomfortable with this conclusion, it may be useful to explore briefly whether any distinctions can be drawn between travel and entertainment and the other items described above.

An obvious distinction is that it may not be feasible to tax some of these items. Unlike travel or entertainment, no one can buy prestige or the right to argue a case independently of the job in question. Thus, there is no objective market price to serve even as the starting point in attempting to measure personal satisfaction. In the absence of such easily ascertainable objective valuation, not only is taxation not administratively feasible, but also it is unlikely to obtain sufficiently widespread acceptance among taxpayers. ${ }^{44}$ For similar reasons, it is not possible to include in income or consumption what the economist refers to as consumer surplus. ${ }^{45}$

However, people do pay to go to the World Series game being covered by the local sportswriter, or to go to the theater on opening night and sit in front of or behind the New York Times drama critic. Thus, a market value can be found for these kinds of benefits. Nevertheless, if it is accepted that the psychic pleasure that comes from doing one's job cannot ordinarily be valued, there is an inconsistency in having an exception simply because one person's job involves an activity that comes close to being something people pay to do. Again, it may be difficult to obtain public acceptance of such a distinction.

The exclusion of psychic benefits from the tax base may also be defended on the ground that the tax base should be confined to economic goods, those which can only be enjoyed at the expense of reduced enjoyment by others. There are limits on the amount of goods and services our society can produce. On the other hand, if a lawyer enjoys his court appearances or gets along well with his wife and children, it has no effect on the ability of others to do the same. Although one purpose of an income tax is the more equal distribution of income, it cannot transfer happiness. Similarly, if the purpose of an income tax is to draw resources away from the private sector in favor of government expenditures, ${ }^{46}$ it cannot deal with prestige, love or friendship, which cannot be utilized to balance the budget.

\footnotetext{
14 Klein, supra note 17 , at 884 .

${ }^{45}$ See note 23 supra \& accompanying text. Thus, if a loaf of bread costs $50 \%$, it is necessary to assume it brings $50 x^{\prime}$ of satisfaction to all who buy it, even though it is clear that not all buyers value bread equally. The additional consumption of those persons who would be willing to pay more than $50 x$ is ignored by the law.

${ }^{46}$ See Andrews, supra note 32 , at 325-26.
} 
Ultimately, this analysis is unsatisfying. Of course, the tax cannot be collected in the form of prestige or love, but this does not explain why the cash to be collected cannot be determined by applying the tax schedule to a base which would include these items. A tax base comprised of total possible consumption would insure that individuals with equal before-tax income would, after tax, continue to have the same opportunity to achieve personal satisfaction. ${ }^{47}$ After all, the tax cannot be collected in the form of travel, meals, lodging or stock in the corporate employer either. Moreover, it is not so easy to state that such items are distinguishable, because they are in-kind substitutes for what otherwise would be purchased with cash. It may be that a lawyer who enjoys his job, including the excitement of a day in court, will also have less need to spend his money at night clubs or at the movies. Nevertheless, it is not clear that the distinction between travel and entertainment on the one hand and prestige or enjoyment from the direct carrying on of one's work on the other rests wholly on administrative convenience or on public acceptance of the inclusion of such satisfaction in a tax base. In fact, the feeling that the existence of prestige is of no help in paying the tax appears to derive some support from what the economist would refer to as the income effect on the demand for goods and services which would be caused by a tax on such prestige. ${ }^{48}$

To illustrate, suppose an attorney has a choice between law practice with an income of $\$ 100,000$ per year or a position as a law professor with a salary of $\$ 30,000$. Perhaps the teaching job offers more leisure, more prestige and a captive audience several times per week, all of which the attorney finds attractive. In a tax-free world, he equates practice and teaching because he values these noncash benefits at $\$ 70,000$. $^{49}$ At first glance, a tax uniformly applied to all forms of satisfaction would not seem to affect this equation. But, if the tax on $\$ 100,000$ of income were

${ }^{47} I d$. 326. Use of the income tax to redistribute income would be accomplished by the progressive rate structure and exemptions appropriate to the degree of distribution which is desirable or, perhaps, feasible.

${ }^{18}$ The change in demand caused by a rise or fall in income would be referred to as the "income effect" by economists. Not only does demand fall as income declines, but also the ratio of income devoted to various goods may increase or decrease. A. Alchian \& W. Allen, University Economics 73 (3d ed. 1972).

${ }^{49}$ Moreover, because of the tax law the lawyer might well turn to teaching even though he does not value these intangibles at $\$ \mathbf{7 0 , 0 0 0}$. If after tax the law practice will provide only $\$ 70,000$, while the tax on a cash income of $\$ 30,000$ is say $\$ 5,000$, the two positions are equally desirable if the intangibles are worth only $\$ 45,000$, the after-tax return on the additional $\$ 70,000$ of cash. Thus, because such intangible benefits are not taxed, the present income tax probably results in an increase in the number of teaching jobs or a reduction in the cash salary necessary to attract teachers. 
$\$ 30,000$, and if, as hypothesized, the teaching salary were just $\$ 30,000$, there would be insufficient cash available to pay the tax. It would appear, therefore, that such a tax would drive the attorney out of a teaching job.

On closer examination, it would seem that the problem created by a tax on these psychic benefits is similar to the difficulties that one would experience if the market value of on-the-job entertainment were included in his taxable income even though this amount exceeded his personal satisfaction. For example, suppose a salesman received $\$ 30,000$ in cash and his employer spent $\$ 70,000$ on his share of entertainment, an amount far above the salesman's personal valuation. At first glance, the professor's situation seems to be different, because it was postulated that he values the psychic benefits at $\$ 70,000$. However, while this is correct if there is no income tax, or if such benefits are not subject to tax, it is not true if the psychic benefits are subject to tax. To put it another way, the salesman and the professor might be satisfied with cash of $\$ 30,000$ and noncash benefits of $\$ 70,000$ when there is no tax, or with after-tax cash income of $\$ 25,000$ and $\$ 70,000$ of benefits in kind. But neither is likely to want so much in kind when all their cash earnings are consumed paying tax, and they are left with only inkind compensation.

Similarly, a theater critic's satisfaction from viewing a play determined in a world without an income tax or at his current level of cash income does not necessarily accurately measure what his satisfaction would be if his cash income were reduced by a tax imposed on the noncash benefits. The change in satisfaction would be influenced by whether the noncash items are necessities or luxuries and the significance of the reduction in cash income, which in turn would depend upon the ratio of the value of noncash amenities to total income from the job.

Thus, the difference between the value placed on an item in a world without an income tax, as compared to a world in which all satisfaction is taxed, may be particularly great with respect to prestige and to the satisfaction from direct performance of the income-producing activity-such as viewing the play, in the critic's case. ${ }^{50}$ In addition to the reasons discussed above, the

5n It is conceivable that unless the attorney can have a cash income of $\$ 25,000$, he would not place any value at all on the intangible benefits of the teaching profession. In the circumstances where the lawyer values the noncash benefits at $\$ 70,000$ when he has cash of $\$ 30,000$, and at zero when his cash income is reduced below $\$ 25,000$, the adoption of an income tax based upon full consumption would discourage teaching by those who get significant psychic benefits from the job. The teaching job would certainly 
criteria, described in Part III, to be used in applying the theory developed in this Part to the real world may suggest nontaxation both of the critic's noncash remuneration, and of the satisfaction from the physical nature of the job-site, which has yet to be distinguished from travel and entertainment. ${ }^{51}$

\section{Applying the Test in the Real World}

\section{A. Introduction}

Since it is impossible to measure personal satisfaction on a case-by-case basis, perfect measurement of net income cannot be achieved. Either overstatement or understatement of income is inevitable. Nevertheless, guidelines can be developed which will indicate the possibility that a certain kind of expenditure will yield personal satisfaction equal to cost, or no personal satisfaction at all. If the guidelines indicate that the possibility of personal satisfaction being equal to cost is a reasonable one, then no deduction should be allowed or the recipient should be taxed.

Of course, there will be some such situations when personal satisfaction will not in fact equal cost. However, as discussed below, a strong case can be made that the consequences of a failure to tax actual income are much worse than the consequences which would result from the taxation of an overstated income. Therefore, complete certainty is not necessary to justify the assumption for tax purposes that the recipient of a benefit would pay the market price for the benefit obtained. In short, a reasonable possibility of the presence of income should be a sufficient ground for taxation.

There will always be cases where the guidelines will not point unambiguously in either direction. However, in situations where the size of the questioned expenditure is relatively small or, if large, is -spread out in fairly equal amounts to a large proportion of taxpayers, whichever rule is adopted will not have a pronounced effect on tax equity. The result in such cases might properly depend upon considerations of administrative convenience. This approach would suggest, for example, the denial of a deduction where the taxpayer makes an expenditure

require a higher salary to be attractive to those persons. However, the school, which would try to keep the increase as small as possible, may hire someone deriving less psychic benefit from teaching, who will work for $\$ 35,000$ because this is only slightly less than he could otherwise earn. The possibility of such results may make one feel more at ease with the nontaxation of prestige and similar satisfactions.

${ }^{51}$ See text accompanying note 65 infra. 
to benefit himself, while at the same time excluding from income similar benefits provided by an employer to a large number of employees. At least, such factors could be considered controlling where the possibility of planning to take advantage of the lack of symmetry is minimal. ${ }^{52}$ However, the question still remains as to what is to be done in those cases where the guidelines are of little help, and there is a large and relatively concentrated expenditure where a great deal depends on the development of the applicable rule.

Allocation of the deduction based upon the ratio of business value to the total of the business and personal valuations has not yet been specifically rejected as a possible procedure. However, if the approach suggested in Part II is followed, allocation is logical only if the total of the business and personal valuations is not greater than cost. In any other situation, this method of allocation will permit some amount of consumption to be untaxed. Nevertheless, as will be discussed in Part IV, Section E, relating to travel expenditures, in some circumstances there may be no choice but to attempt to develop a formula for allocation between the personal and business components. Travel expenditures, for example, can be allocated based upon the total time devoted to business as compared to the total time of the trip.

Comparative use is not always apparent, however. How, for example, could the amount of time a college education is used for business purposes be compared with its personal use? Therefore, unless another measurement could be found, it would seem that allocation would be totally arbitrary in many circumstances ${ }^{53}$ and that the use of this method should be kept to a minimum.

\section{B. Developing Guidelines}

Ultimately, guidelines should aid in resolving the issue whether there is a reasonable possibility that an expenditure

52 It is understood that the Internal Revenue Service is willing to wink at some employer-supplied fringe benefits, e.g., parking spaces, at least as long as the amounts involved are relatively minor. See Harvard UnIVERSITy, InTERnational Program in Taxation, Taxation in The United States 538 (1963). It may not be so clear, however, that everything which is ignored in this manner is minor. How many pay tax on the significant personal benefit derived from being driven to work each morning in a corporate or government car? It has also been implied that academics get significant amounts of tax-free income from the use of university facilities. See Bittker, supra note 17. at 953 n.46.

${ }^{53}$ Prior to the Supreme Court decision in Fausner v. Commissioner, 413 U.S. 838 (1973), some courts were willing to allow a taxpayer who would have driven to work in any event to deduct a portion of the commuting costs if the need to transport "tools" would have required the use of a car. This kind of arbitrary allocation was derided by the Fifth Circuit as random speculation. Fausner v. Commissioner, 472 F.2d 561 (5th Cir. 1973). 
yields personal satisfaction equal to cost. There are at least four factors which should be considered in this connection:

1. The degree of certainty as to the business benefit to be obtained.

2. The degree of certainty as to the existence of personal enjoyment.

3. The possibility of both business and personal satisfaction from the same expenditure.

4. Payment by the individual benefitted or by another party. ${ }^{54}$

\section{Certainty of Business Connection}

The existence of a clear business purpose for a transaction makes it difficult to assert that "there must be a personal benefit, since otherwise the transaction would not occur." In addition, regardless of personal benefit, to the extent that the return in terms of business benefit would not justify the expenditure, a deduction should not be allowable. Indications that personal satisfaction would not justify the full cost do not necessarily indicate the existence of a business benefit. For example, even Solely Pleasure would buy the $\$ 25$ football tickets despite a feeling they are worth only $\$ 12.50$ from the personal standpoint, if the cost were deductible and he were in a 50 percent tax bracket. Although ordinarily the taxpayer's judgment is not examined as to whether advertising or research, for example, is a wise expenditure, in regard to personal benefit such questions seem inevitable.

One method of assuring a reasonably strong business connection is to require initially that the principal purpose of the expenditure be for business. Hopefully, such purpose could be established by objective criteria. ${ }^{55}$ For a particular event, such as a dinner in a restaurant or an evening at a night club, the law has generally required a showing that business reasons are primary. On the other hand, the cost of an asset, such as a home or a car, allocable to business has generally been deductible despite the fact that the asset was used primarily for personal purposes. The general rule was modified in 1962 to deny a deduction for depreciation or maintenance of facilities used for entertainment unless the primary use of the facility was in connection with the

${ }^{54}$ The application of these factors in evaluating the tax treatment of various items is presented in Part IV, infra.

${ }_{55}$ A stronger position would require proof that business reasons were clearly sufficient to justify the transaction, as would be the case with All and Enough Business. 
taxpayer's trade or business. ${ }^{56}$ Possible extension of this rule to a home office should be considered. One objection to this approach is that certain activities, although engendering significant personal enjoyment, would not occur but for some business objective which might not be characterizable as the "primary" purpose of the expenditure-the case of Neither Alone. It has been argued in this Article that it is theoretically logical to allow a partial deduction in such a case. Nevertheless, the practical difficulties of calculating such a deduction are formidable. Moreover, the theoretical inequity of not allowing a partial deduction is somewhat ameliorated when one considers that in most instances where a deduction was justifiable, the principal purpose of the activity would be business. When the principal purpose is not business, the theoretically ideal deduction would be something less than half of the total expenditure, and thus the harm resulting from disallowing the entire deduction would be relatively small.

\section{Certainty of Personal Benefit}

As indicated, the introduction of a business motive makes it impossible to be sure that personal satisfaction is as great as cost. Not only might the taxpayer not otherwise engage in the activity, but the business setting may diminish his personal satisfaction. Nevertheless, in some circumstances there are grounds for relative certainty that personal satisfaction exists. Business entertainment cannot. fulfill its intended function, unless someone derives personal satisfaction from it. Food and clothing will definitely be obtained in some form and, while it is conceivable that no satisfaction will be obtained from the hundredth restaurant dinner of the year, in most cases some personal benefit will be produced. Similarly, although it is not possible to say that just as everyone eats three meals a day, everyone goes to college, it is true that for a segment of society a college education will be sought just as universally and without regard to its effect on future earnings.

In other cases, objective evidence of the existence of some personal benefit may be available - the use of the extra room in the house for personal reasons, or the extension of a business trip to Europe to take a one week vacation. On the other hand, if a businessman travels to a city not known for its attractiveness to vacationers, there is an indication of the absence of personal benefit.

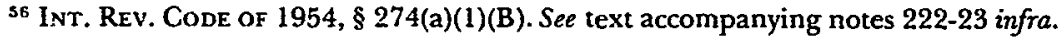


Individual preferences for travel and other forms of entertainment or recreation will vary, but, as described in Section C of this Part, an individual's choice of jobs may give some indication of the strength of his particular preference. Thus, the person choosing a job with a significant entertainment component is likely to be the one who values entertainment most highly.

\section{Inconsistency of Business and Personal Enjoyment}

In some situations, it will be impossible for the personal satisfaction from an expenditure which is at least partly business related to be equal to cost. This will be true, for example, where there is a physical limitation on use of an asset, as in the case of an automobile. If it is assumed that a car will last a relatively fixed number of miles, and that there is no pleasure derived from a business trip, then if it is driven 2,000 miles for business purposes, that represents 2,000 fewer miles that it can be driven for pleasure. Since ordinarily individual valuations are ignored and it is assumed that a car is worth no more than its market price, if the interference of business use is absolute, the sum of personal and business benefit equals cost and no more. Therefore, the relative value of each use can be measured by the time the car is used for business as compared to pleasure..$^{57}$

On the other hand, there will be many instances where the business aspects of a pleasurable activity will not necessarily interfere with the personal benefit derived from it. Thus, the total benefit from the expenditure could exceed the actual cost. ${ }^{58}$ This is true of the cost of the airline tickets for a combined business-pleasure trip, if the traveler takes the additional time

${ }^{37}$ It may be suggested that businessmen buy luxury cars to be used primarily for pleasure, and thereby increase satisfaction, only because they can deduct the cost of the business use. For example, a businessman may determine that the needs of his business would justify spending $\$ 16,000$ annually on an automobile while he would only spend $\$ 8,000$ for a pleasure vehicle. Since he has the $\$ 16,000$ car anyway, he uses it half the time for pleasure. Even assuming he does not overstate his business use, he still has the advantage of driving a $\$ 16,000$ car with a nondeductible outlay of only the $\$ 8,000$ he was willing to spend on a pleasure vehicle. Surely his satisfaction must increase. However, if the car were used solely for pleasure, it would last longer and he would get more use out of his $\$ 8,000$. He now may be spending $\$ 8,000$ per year while a pure pleasure car would last for two years. At $\$ 8,000$ per year he could have bought the $\$ 16,000$ car totally apart from the business use. If there appears to be something wrong with the logic of this example, it may be that a car does not have within it a relatively fixed number of miles. To a man who will buy a new car each year anyway, the business use might not detract from the personal pleasure from the car. The option of a $\$ 16,000$ car every two years was not a real one.

${ }^{58}$ It may be argued that this position, that total benefit could exceed cost, is inconsistent with the failure to take account of consumer surplus in measuring taxable income. But measurement of individual preferences in order to determine a total valuation in excess of market is not required. What is involved is the assumption that a taxpayer can simultaneously value a benefit at cost in his identity as a businessman and in his identity as a consumer. 
necessary to make his business call, and if having business on his mind does not detract from his vacation. Presumably, a move to Miami because of the climate and because of a job opportunity can be carried out by the same moving truck and in the same airplane, without one aim interfering with the other. If a man gets a certain personal satisfaction from wearing a suit, he could possibly get the same benefit from wearing a suit to the office unless suit-wearing benefits depend greatly on the surroundings in which the suit is worn. While it does seem possible that one who does not need to work may get more personal use out of a liberal education than one who does, the personal benefit of a college education is probably not significantly affected by its usefulness in obtaining a job. The interference with personal satisfaction from the business use of a room in the home, or from entertainment or meals that occur in a business context, would seem to fall between the extremes of relatively absolute interference in the case of the automobile, and the minimal interference involved in travel and education. In any event, as the degree of interference declines, it will be more probable that the personal benefit will be equal to one hundred percent of the cost, and that a deduction will not be justified.

\section{Identity of the Payor}

The fact that the individual is not the payor may be some indication of his lack of personal benefit, because in such circumstances he may have less control over the selection of the activity involved. ${ }^{59}$ Thus, in some marginal cases, employer or third party payment may justify nontaxation of the benefit. However, it should not have much of an effect as to meals, lodging, travel, entertainmert and the other items discussed in this Article. With regard to these items lack of complete control would have less effect on the likelihood of receiving significant personal benefit.

Therefore, in many circumstances travel and entertainment paid for by an employer, client or supplier and received by employees or customers should result in taxable income. ${ }^{60}$ Such a proposal, however, involves certain problems. Presumably

${ }^{59}$ See Treas. Reg. \& 1.274-4(f)(5)(i) (1963).

${ }^{6 n}$ If one's dinner is purchased by a friend, it is exempt from tax as a gift. INr. REv. CODE of 1954, $\$ 102$. Although there is not likely to be an intention of making a gift to a customer, the regulations imply that a gift is possible at least as to tickets of admission if the seller does not accompany the customer to the event. Treas. Reg. § 1.274-2(b)(1)(iii)(b)(2) (1963). This does not interfere significantly with the proposal to be advanced, since the Code limits the deduction for gifts to individuals to $\$ 25$ per donee per year. INT. REv. CODE of 1954, $\$ 274(\mathrm{~b})$. 
there will be cases where it will be difficult for an employer to allocate its costs to particular employees. More significantly, it is at least unwise to attempt to tax the customer when a salesman takes him to dinner. Certainly it would be an undue interference with business to require notification to the customer of the amount spent to entertain him.

These are not insoluble problems. In many cases, total tax collections that would result from inclusion of such benefits in income could be approximated by a rule denying a deduction for particular expenditures unless the payor designated the beneficiaries. This could be accomplished by filing an information return with the Internal Revenue Service and sending a copy to the beneficiary. If the beneficiary received such an information return, he would be taxable; otherwise not.

For example, assume the Widget Corporation of America spent $\$ 100$ entertaining Smith, a potential buyer of widgets. If the corporation could deduct the expenditure, its out-of-pocket cost at a forty-eight percent tax rate would be $\$ 52$. If Smith were taxed at a fifty percent rate, the Internal Revenue Service would get $\$ 50$ from Smith, who would have a net benefit of $\$ 50$. If the expenditure were not deductible by Widget because it was not reported as taxable to Smith, then the Service would collect an additional $\$ 48$ from the corporation. In these circumstances, the corporation would be out $\$ 100$ and Smith would be $\$ 100$ ahead, but this increase in the corporation's costs presumably would be reflected in the price of widgets or in other transactions between the corporation and Smith.

A similar approach is reflected in the current exemption from the special limitations on entertainment expenditures of "expenses for goods, services, and facilities, to the extent that expenses are treated by the taxpayer, with respect to the recipient . . . as compensation to an employee." 61 If this rule would take hold, the suggestion made earlier ${ }^{62}$ that small employersupplied benefits should, in the interest of convenience, not be taxed is unnecessary. It would be possible to deny a deduction to the employer, unless income is allocated to particular individuals.

Differences between employer and employee tax rates may cause a distortion in some circumstances. However, if the fifty percent maximum tax on earned income ${ }^{63}$ becomes generally

${ }^{61}$ INT. REv. CODE of 1954, \& 274(e)(3).

62 Note 52 supra \& accompanying text.

${ }^{63}$ INT. REv. CODE OF 1954, $\S 1348$. For a description of the circumstances in which the limitation would not apply, see Halperin, Maximum Tax Not for Those Indulging in Deferred Compensation and Tax Preferences, 24 Major Tax Planning 619 (1972). 
applicable, individual rates will not ordinarily be significantly higher than the tax rate on corporations, thus minimizing the distortion. Therefore, in light of the administrative difficulties of taxing the recipient, it is acceptable to leave the choice of who pays the tax to the parties. The most serious problem would involve expenditures by government or tax-exempt organizations, which would not lose a deduction as the price of providing tax-free enjoyment to others. It would not seem impossible generally to impose a tax on the beneficiaries in these cases. ${ }^{64}$

\section{Application of the Guidelines}

The guidelines may offer support for the nontaxation of benefits derived from direct performance of the job (like the critic's) or from the physical nature of the job site (like office furnishings), although the conclusion as to the latter is more questionable.

\section{a. Direct Performance of the Job}

Testing for a sufficient business connection, the necessity of the critic attending the play or the trial lawyer appearing in court is obvious. The personal satisfaction may also be less than one would expect in the case of a critic or a sportswriter who is working at his job while at the entertainment event. The lawyer, entertaining an out-of-town client, may be able to sit back and enjoy the play as much as the person in the next seat who is there with his spouse. The critic must think constantly of his review, and he is not able to choose which plays he will see and review.

Since the critic is paid to watch the play, it may be argued that his enjoyment is not seriously affected by these difficulties. But it seems impossible to determine case by case whether the job interferes with watching the event. For example, consider the situation of a producer, cameraman, statistician and announcer all working on a TV football broadcast. It may be better to assume that all suffer reduced enjoyment.

Moreover, few if any people go to as many sports events as a sportswriter whose entire job consists of reporting such events. A salesman entertains customers as only part of his selling efforts and often outside his normal working hours. True, the sportswriter or the theater critic is likely to be the person who

${ }^{64}$ Cf. CARTER REPORT, supra note 41 , at $288-89$ (suggesting penalty tax on employers which could also be applied to tax-exempt institutions). 
most enjoys sports or the theater. Still, when entertainment is the stuff of which the entire job is made, there is less reason to feel confident that personal satisfaction will equal cost-especially when the effects of the reduced after-tax income from taxation of all benefits is considered. ${ }^{65}$

\section{b. Job Facilities}

With regard to the business use of a luxury car, while there is no assurance that the use of a Cadillac makes it likely one will make more money than he would if customers were visited in a Chevrolet, there is evidence that at least part of the cost has a business purpose. This is not necessarily known in the case of a visit to a night club or a cruise on a yacht.

In measuring personal satisfaction, the proper question may be how much would have been paid for the ride in the Cadillac, the air conditioning in the factory, the first class airplane ticket or the paintings on the office wall, assuming there was no business need to be on the plane or in the car, the factory or the office. It is not unlikely that the answer will be nothing, at least as to the air conditioning and the automobile ride. For one thing, the personal and business use must be simultaneous. Being forced to drive where customers are located or to be at work in a factory probably significantly diminishes the personal satisfaction from the car and the air conditioning. Furthermore, the employee may have air conditioning available at home which is being used in any event for the comfort of his wife and children, so that the job provides only duplicative benefits. Similarly, if he were not working, he might be able to keep cool without cost by sitting in the park, or substitute for the comfort of a Cadillac by lying down on the living room couch.

Nevertheless, this analysis is too simple in that it looks to the choice between working and not working. The fact remains that, given the necessity of working, the businessman chose to make $\$ 97,000$ a year and to use a Cadillac for business trips, as opposed to making $\$ 100,000$ and using a Chevrolet. Is not the real income in both cases $\$ 100,000$ ? On the other hand, is it helpful to say that the purchase of the Cadillac represents an incomplete acceptance of the choice of work over leisure, not markedly different from working fewer hours, making only $\$ 97,000$ and enjoying $\$ 3,000$ more in leisure instead of in cars? Although there does not seem to be a completely satisfying

${ }^{65}$ See text accompanying notes $46-48$ supra. 
answer, there appears to be justification for taxation of luxury facilities where administratively feasible.

For example, it seems clear that no deduction should be allowed for the cost of food in excess of a relatively modest amount per day. While it is possible that a person would prefer a simpler meal with his family and would pay nothing to eat in a restaurant, it appears more reasonable to assume that at least some of the extra cost of a high-priced restaurant meal provides personal satisfaction. Perhaps this conclusion is influenced by the feeling that there is a personal benefit equal to the entire cost of the food. Since no deduction is justified, one can hardly object to only a partial disallowance. However, it also seems reasonable to place a dollar limit on the deduction for out-of-town lodging even if the hotel room is in a city which would obviously not be visited for personal reasons. Perhaps again this is influenced by an assumption that the percentage of cases where the individual would pay full value for the hotel room, even in the absence of business considerations, is greater than it would be for the use of a car or a luxurious office. Nevertheless, this is not a wholly satisfying distinction. For example, this exercise in line drawing may put first class air fare on the side of hotel rooms rather than automobiles. The need for an easily administerable rule may suggest that it is impossible to place a dollar limit on the cost of office furnishings, but this would not preclude a maximum deductible cost per mile for a car used for business, or a limit on the deduction for air travel to the cost of a coach ticket. Such a limit should be considered.

\section{Procedure in Uncertainty}

Nontaxation of real income in the form of goods and services enjoyed in connection with work is unfair to taxpayers who do not enjoy such income, and it distorts economic activity by causing overutilization of these items. If an individual values a form of entertainment at $\$ 2,000$, he will obviously prefer $\$ 3,000$ in cash which he can spend as he likes. However, if the cash is taxed at a rate of forty or fifty percent, then the untaxed entertainment becomes more valuable. There would thus be a tendency to increase the untaxed component of one's income over the amount that would be expected in an income-tax-free world.

This practice increases the unhappiness of those whose work does not permit arrangements for tax-free consumption. The 
realization that his tax load is increased due to the failure of those who can say "it's deductible" to pay their fair share has an effect on the morale of the ordinary taxpayer. ${ }^{66}$ Ultimately our self-assessment system depends on a high level of taxpayer morale.

On the other hand, if goods and services enjoyed on the job were assumed for tax purposes to be worth their market price, it would be unfair to those individuals whose personal satisfaction was significantly less. The chances for tax equity would be greater if the bias were in this direction, however, since in many circumstances it is reasonable to expect personal benefit equal to cost. If this is not the case, the affected individuals might be able to reduce their usage of the overtaxed items, thus bringing taxable income more in line with personal enjoyment. They certainly would no longer have an incentive to overindulge. For these reasons and because of the concern for taxpayer morale, it would be better to assume that goods and services are worth the market price to the individual as long as there is a reasonable possibility that this is true.

Acceptance of this position requires consideration of whether reduction in the use of the goods and services, most significantly entertainment, which would in some circumstances be overvalued under the proposal advanced in this Article would involve an unwise interference with economic behavior. Although the discussion which follows is undoubtedly oversimplified, it is hoped that it gives a fair indication of the relevant questions.

\section{Effect on Behavior-In General}

Even in a tax-free world, there is a bias in favor of activity which will serve the dual purpose of producing income and providing personal satisfaction. All other things being equal, education would be favored over other methods of increasing income, because it has the by-product of personal benefit. Similarly, if a $\$ 100$ expenditure on either advertising or entertainment is likely to produce $\$ 200$ of income, but the entertainment expenditure also provides $\$ 50$ of personal satisfaction to an employee or a customer, entertainment will be preferred since it will enable the employer to lower the cash compensation to the employee or raise the price to the customer.

${ }^{66}$ Hearings, supra note 8 , at 1687 (testimony of leading accountant); S. REP., supra note 10, at 407, 1962-3 Cess. BuLl. 1110 (minority views of Senators Douglas and Gore); Bittker, supra note 17, at 953; 3 CARTER REPORT, supra note 41 , at 4.3 . 
This process should insure that if anyone values the entertainment component of a job at its market price, that person will get the job. For example, suppose there are two individuals, alike in abilities but with different tastes for entertainment, who are applicants for a job requiring its holder to entertain customers at night clubs 100 times during the year. Assume that the cost to the employer of the employee's share of the entertainment is $\$ 3,000$ annually. Swinger, who enjoys night clubs, would accept the job at $\$ 15,000$ per year, but Holmes, who obtains no personal satisfaction from a night on the town, would insist on $\$ 18,000$. Since Swinger and Holmes are assumed to be equally good salesmen, Swinger, who will work for less money, will get the job. Holmes will look for a position paying $\$ 18,000$ in cash. ${ }^{67}$

But suppose that, perhaps because the amount of entertainment required by the job is so great, no individual can be found who personally values the entertainment at its full market price. For example, suppose Swinger is required to go to a night club 200 times per year at a cost to his employer of $\$ 6,000$, but neither Swinger nor anyone else would pay more than $\$ 3,000$ for the privilege.

The burden of a tax measured by the cost of entertainment could fall on Swinger if he is unable to secure another job. If Swinger has a number of job opportunities, the employer will have to raise Swinger's cash income above $\$ 15,000$ to compensate for the overtaxation of entertainment, unless he can reduce the entertainment content of the job to a point where the cost will not exceed Swinger's personal satisfaction of $\$ 3,000$. Either course could in effect result in a price increase. Thus, if the employer pays Swinger a higher salary, he may be able to pass on the cost to customers. Similarly, if entertainment is a means of effecting a rebate in price to customers or their employees, any

${ }^{67}$ The existence of an income tax would have no effect on the result if Swinger's personal satisfaction of $\$ 3,000$ were properly measured. If the consumption benefit in the form of entertainment were not taxed, presumably Swinger would be willing to accept less than $\$ 15,000$ in cash as long as the total of the cash left after tax and the $\$ 3,000$ of in-kind benefits is not less than the net after-tax income from $\$ 18,000$ of cash compensation. This would further insure that the compensation would be driven too low to make it acceptable to someone like Holmes, who gets no personal satisfaction from the entertainment. Failure to tax by lowering the cost to the employer without reducing the employee's compensation would also have the effect of increasing the utilization of entertainment. This is part of the economic distortion that comes from failure to tax certain forms of compensation.

Personal taste for entertainment may not be a determinant of job selection if the benefit is not an important enough component of the job for persons in that labor market properly to take cognizance of it. For example, entertainment might not be a sufficient element of an attorney's work to affect anyone's decision to become a lawyer. In those circumstances the cost of such benefits would probably not be great, and the consequences of an overevaluation of them should not be serious. 
reduction in Swinger's entertaining is an indirect increase in price.

If Swinger bore the burden, there would be a decline in his income and an inequity in the application of the tax since he would be taxed on more than he actually received; but there would be no change in the use of entertainment. In some circumstances, however, placing the burden on the employer would affect such usage. ${ }^{68}$

For example, assume Swinger can earn $\$ 18,000$ in another job. The salary he would demand from a job providing entertainment would depend upon his tax bracket and the personal enjoyment derived. If Swinger were in the 50 percent bracket and valued the entertainment at $\$ 3,000$, the tax measured by the $\$ 6,000$ cost of the entertainment would offset the personal satisfaction obtained. Thus, he would insist upon cash compensation of $\$ 18,000$.

If the amount spent entertaining customers was as productive of income as alternative means of doing business, it would not be necessary for the employer to change his method of operation. The bias in favor of activities providing personal satisfaction is eliminated, but entertainment remains as viable as other business expenditures. Both now require a salary of $\$ 18,000$. But suppose $\$ 6,000$ spent on entertainment produced only $\$ 9,000$ of gross income, while $\$ 6,000$ spent in other ways would increase gross income by $\$ 12,000$. If the entertainment benefit were not taxed, or were taxed but accurately measured, the outlay would be justified since it would permit the employer to hire Swinger at $\$ 15,000$ per year rather than Holmes at $\$ 18,000$. Thus the return in effect is $\$ 12,000$ on entertainment as well. If Swinger's taxable income is increased by $\$ 6,000$ as a result of the entertainment, however, he will insist on a salary of $\$ 18,000$ and the entertainment will no longer be economical.

Nevertheless, as long as the tax on the value of entertainment does not exceed the personal satisfaction obtained by the employee, an employer, even one who bore the full burden of the extra tax on entertainment, could consider and utilize entertainment as any other expenditure of producing income. If personal satisfaction obtained from entertainment equalled at least half the cost, and the maximum tax on earned income were 50 percent $^{69}$ the tax could not exceed the personal benefit. Thus,

${ }^{68}$ The analysis would be identical for a self-employed individual who could avoid the excess tax burden only if he could pass it on to customers.

${ }^{69}$ See note 63 supra. It is reasonable to assert that those whose use of tax preferences 
it is reasonable to believe that valuing entertainment at cost would cause a reduction in its use only in those cases where it is presently used purely because it enables the employer to pay lower salaries than his employees would otherwise command.

To summarize, if it seems possible that some people can derive enjoyment equal to the market price of job-related activities, it is reasonable to assume that such persons are the ones likely to take the job. Even if it seems unlikely that any one would value the benefit so highly, if it is reasonable to assume a personal benefit equal to at least one-half of the cost, entertainment will still be as useful as other forms of doing business, despite a tax on the employee based upon market value. Although if there is over-valuation there will be some decline in the use of entertainment compared to its use in an income-tax-free world, this distortion is much less serious than the overutilization that accompanies a failure to tax actual satisfaction.

In fact, it is possible that a decline in entertainment would increase efficiency. The use of entertainment implies an attempt to sell products by making the buyer like the seller, or more probably by offering the buyer or its employees a price rebate in the form of entertainment. Since not everyone values entertainment at cost, a direct price reduction would be more efficient. It may be that an increased tax burden on entertainment would force marginal companies which have no alternative means of selling their goods out of business. But this would not be harmful if it encourages the growth of other firms that sell on a more rational basis. Therefore, it is concluded that the possibility of interference with economic behavior is not serious enough to override the tax equity considerations which suggest that there should be a bias toward taxation in excess of personal satisfaction, as opposed to a failure to tax such satisfaction.

\section{More About Critics}

The conclusion may be different if the entertainment concerned is directly involved in performing a job, as is the case with a theater critic or a sportswriter. In these circumstances, the alternative of reducing the entertainment component of the job is not available. A salesman can still sell if he entertains less, but a theater critic must go to plays in order to review them. The only possible adjustments if the personal satisfaction from on-the-job benefits is overestimated, are higher salaries for critics or elimi-

prevents them from taking advantage of the $50 \%$ maximum rate are not worthy of concern. 
nation of the job. This seems potentially more disruptive than the effect on the salesman.

Thus, one might want more assurance that the critic receives satisfaction equal to market cost before imposing a tax on that basis. As previously discussed, despite the self selection which would cause those who most enjoy the theater to become critics, there is not adequate assurance that the benefit is ever this great. $^{70}$

\section{Evaluation of Present Law}

In this Part, present law is examined to see if the rationale implicit in the existing rules can be determined. Such rationale as can be found will then be examined in light of the previous analysis. Necessarily, the statement of existing law will have to be brief, and some omissions are unavoidable.

\section{A. Education}

\section{The Law}

Since 1958, educational expenses have been deductible if the education maintains or improves skills which are required by the individual in his trade or business, or is required by the taxpayer's employer or by law as a condition of continued employment. ${ }^{71}$ In order to qualify, a taxpayer must have already attained at least the minimum educational qualifications for his job, and must show that the education would not qualify him for a new trade or business. ${ }^{72}$ These two restrictions make it difficult to deduct the cost of any education which leads to a degree, with the exception of some graduate education in the same field as a prior degree. $^{73}$

Before 1950, even this parsimonious approach would have seemed revolutionary, as the IRS and the courts, adopting what

${ }^{70}$ See text accompanying notes $46-48$ supra.

$\because 1$ Treas. Reg. $\$ 1.162-5$ (1958). At an earlier time a deduction was allowed only if the education was required by the employer. I.T. 4044, 1951-1 CuM. Bull. 16; Proposed Treas. Reg. 1.162-5(d), 21 Fed. Reg. 5093 (1956). See Wolfman, Expense, supra note 16, at 1102 n.63. Since the employer-requirement test is not met unless the "requirements are imposed for a bona fide business purpose of the individual's employer," Treas. Reg. $\S$ $1.162-5(c)(2)$ (1967), it may be difficult to meet this condition without also satisfying the first test.

${ }_{72}$ Treas. Reg. \& 1.162-5(b) (1967).

${ }^{73}$ See Rev. Rul. 69-199, 1969-1 Cum. Butl. 51. But see John D. Glasgow, $31 \mathrm{CCH}$ Tax Ct. Mem. 310 (1972), aff'd per curiam, 486 F.2d 1045 (10th Cir. 1973) (Baptist minister allowed to deduct the cost of a B.A. degree). Although the case was decided under the 1958 regulations, the court found that the taxpayer's bachelor degree did not qualify him for a new trade or business. 
they took to be Justice Cardozo's dictum in Welch $v$. Helvering, ${ }^{74}$ held that educational expenses are personal and denied all deductions. Nora Payne Hill ${ }^{75}$ provided the breakthrough, as the Fourth Circuit reversed the Tax Court's conclusion that the summer school expenses of an experienced teacher were personal, finding them both "ordinary" (normal incident for teacher) and "necessary" (required for continued certification). ${ }^{\mathbf{7 6}}$

According to the regulations, the fact that an individual is performing a job does not establish that he has met the minimum educational requirements. ${ }^{77}$ Thus, the cost of a bar review course is not deductible, even if one attends at night while working for a law firm during the day. ${ }^{78}$ But a teacher need only show that he has attained the level of education normally required for initial hiring as set by law or custom. This is so even though all teachers might be required to obtain additional education, such as a master's degree, within a relatively short period of time. ${ }^{79}$ College instructors who need a Ph.D. for permanent affiliation, however, would apparently generally not be able to take advantage of this more liberal rule to deduct the cost of their graduate education. ${ }^{80}$

Since 1967, the regulations have denied a deduction to anyone who qualifies for a new trade or business regardless of his motivation for seeking more education. ${ }^{81}$ Prior to that time, the taxpayer's primary purpose was crucial. ${ }^{82}$ This change has

${ }^{74} 290$ U.S. 111, 115 (1933). For an argument that Justice Cardozo was misinterpretèd and was using the term "ordinary" only to distinguish between current and capital expenditures, and not between personal and business expenses, see Wolfman, Expense, supra note 16 , at $1095-97$.

${ }^{75}$ Hill v. Commissioner, 181 F.2d 906 (4th Cir. 1950), rev'g 13 T.C. 291 (1949).

${ }^{76} 181$ F.2d at 909.

"7 Treas. Reg. \$ 1.162-5(b)(2)(i) (1967). See, e.g., Lonnie R. Lenderman, 22 CCH Tax C. Mem. 511 (1963).

${ }^{78}$ Treas. Reg. $\$ 1.162-5($ b)(2)(iii) example (3) (1967).

${ }^{79}$ See Treas. Reg. $\$ 1.162-5$ (b)(2)(ii), (iii) (1967).

${ }^{80}$ Id. \& example (2); Arthur M. Jungreis, 55 T.C. 581 (1970). In Jungreis, the court denied a deduction to a teaching assistant, finding inter alia that a Ph.D. was the minimal educational requirement for the job he sought. Some persons at the instructor level may be more successful, since under the regulations the deduction may be allowed if the doctoral candidate is a member of the faculty and thus has met the standard for initial hiring. This may depend upon whether his service is counted toward obtaining tenure or upon whether he has a vote in faculty affairs. Under the previously applicable principal purpose test, see text accompanying note 82 infra, some taxpayers succeeded in deducting . the cost of a Ph.D. upon a showing that their main concern was retention of their current position. See, e.g., Marlor v. Commissioner, 251 F.2d 615 (2d Cir. 1958), rev'g per curiam 27 T.C. 624 (1956) (opinion relies on Judge Raum's dissent in the Tax Court).

${ }_{81}$ T.D. 6918, 1967-1 CuM. Bull. 36, amending Treas. Reg. $\$ 1.162-5$ (1958). The Tax Court has indicated its approval of the Commissioner's effort to avoid investigation of subjective intent on a case-by-case basis. David N. Bodley, 56 T.C. 1357, 1361 (1971). See also Connelly v. Commissioner, 72-1 U.S. Tax Cas. 19188 (1st Cir. 1971) (per curiam); Wolfman, Education, supra note 16 , at 546 .

${ }^{82}$ Treas. Reg. \& 1.162-5 (1958). 
not affected educators very much since all "teaching and related duties," apparently including the duties of a school administrator, are now considered part of the same trade or business. ${ }^{83}$ Similarly, a psychiatrist studying to be an analyst is acknowledged to be advancing within the same profession. ${ }^{84}$ On the other hand, the new approach has led to the denial of a deduction for the cost of legal education for revenue agents, ${ }^{85}$ accountants $^{86}$ and claim adjusters ${ }^{87}$ who claimed they sought only to improve their skills in their present trades.

The IRS now grudgingly agrees that one who has temporarily ceased to work in order to go to school full time could be taking courses to maintain or improve skills in an existing trade or business, as long as the layoff does not exceed one year. ${ }^{88}$ Taxpayers out of their respective businesses or trades for longer periods have been unsuccessful in their claim of a deduction. ${ }^{89}$

\section{Analysis}

In sum, the regulations allow a deduction for education which maintains or improves skills required by the individual in his trade or business, and which are not part of the minimum educational requirement for the business or part of a course of study leading to qualification in a new trade or business.

It seems true that once the taxpayer has a particular job, there is a more objective measure of the business purpose of the expenditure. For example, music lessons for a concert artist are more clearly business related than piano lessons for the multitude who play for their own personal enjoyment. This could support a rule which would deny a deduction for education unless the individual has established himself in a particular business. Thus, the Internal Revenue Code requires that the taxpayer be "carrying on" a trade or business. ${ }^{90}$ The minimum requirement test might be a necessary adjunct to such a rule, in

${ }^{83}$ Treas. Reg. § 1.162-5(b)(3) (1967).

84 Treas. Reg. \$ 1.162-5(b)(3)(ii) example (4) (1967). See Greenberg v. Commissioner, 367 F.2d 663 (1st Cir. 1966), rev'g 45 T.C. 480 (1965).

${ }^{85}$ Jeffry L. Weiler, 54 T.C. 398 (1970). Cf,, e.g., William J. Brennan, 22 CCH Tax Ct. Mem. 1222 (1963) (expenses allowed under prior regulations).

${ }^{86}$ See Charles W. Berry; 30 CCH Tax Ct. Mem. 465 (1971) (deduction allowed under pre-1967 regulations based upon experienced accountant's subjective intent but no deduction would have been allowed had the current regulations applied).

${ }^{87}$ Compare Robert J. Connelly, Jr., 30 CCH Tax Ct. Mem. 376, aff'd per curiam, 72-1 U.S. Tax Cas. If 9188 (1st Cir. 1971), with Richard M. Baum, 23 CCH Tax Ct. Mem. 206 (1964) (decided under prior rules).

${ }_{88}$ Rev. Rul. 68-591, 1968-2 CuM. Bull. 73. See Furner v. Commissioner, 393 F.2d 292 (7th Cir. 1968), rev'g 47 T.C. 165 (1966).

${ }^{89}$ See, e.g., Don E. Wyatt, 56 T.C. 517 (1971).

${ }^{90}$ INT. REv. CoDE OF $1954 \S 162$. See text accompanyin? notes 117-18 infra. 
order to avoid different results for similar expenditures depending on when an individual obtains a job. For example, one law student might begin part-time work for a law firm during his third year in law. school while. another does not find work until after he passes the bar. It may be unfair for the former to get a deduction for the last year's tuition while the latter does not.91 This consideration does not apply once an individual has met the minimum standard once, which might suggest, for example, that it is incorrect to deny a deduction for the cost of preparing for a second bar examination, particularly since a teacher can deduct an expenditure for courses necessary to qualify in a second state..$^{92}$

Similarly, qualification for a new trade or business may be held to preclude deduction for fear of discriminating between those who, for example, enter law directly and others who might first engage in some generally related field. This would suggest that the regulations correctly consider the position of school principal to be a continuation of the teaching profession, because being principal is a position which ordinarily can be attained only by first becoming a teacher.

Thus, present rules could be explained as being designed to allow deductions even-handedly under circumstances where there is assurance that all those who qualify are actually engaged in the trade or business to which the education relates. But is it necessary to insist upon this condition to be certain that the educational costs are business expenditures? It seems fairly obvious that a good deal of education before one actually begins business can be justified as a business expense on the ground that it will substantially increase the student's earning capacity. ${ }^{93}$

${ }^{91}$ See Arthur M. Jungreis, 55 T.C. 581, 591 (1970). Cf. James A. Carroll, 51 T.C. 213, 216 (1968).

92 Rev. Rul. 71-58, 1971-1 Cum. BuLL. 55. The regulations also allow a deduction to a mathematics instructor who takes courses to qualify as a science teacher. Treas. Reg. $\$$ $1.162-5(b)(3)(i)(b)(1967)$. However, the Tax Court has denied a deduction to a foreign lawyer, Yaroslaw Horodysky, 54 T.C. $490(1970)$, and a foreign dentist, Ansis Mitrevics, $22 \mathrm{CCH}$ Tax Ct. Mem. 271 (1963), on the grounds that they needed the education to meet minimum requirements for practice in the United States, despite previous practice in Europe. Surprisingly, however, the only reason advanced for denying a deduction for the cost of a second bar admission (including in one case the cost of a bar review course) to American lawyers was that the expenditure was capital and not ordinary. Arthur $E$. Ryman, Jr., 51 T.C. 799 (1969); Larry R. Adamson, 1973 P-H Tax Ct. Mem. 473 (1973). There was no discussion in either case of the possibility of amortization.

${ }^{93}$ For a review of the economic literature attempting to establish the rate of return on investment in education, see McNulty, supra note 25, at 43-49. Professor McNulty concludes that, despite the theoretical and empirical difficulties of such research, "a review of the economic literature leaves a residual conviction ... that education does contribute to higher income." Id. 45. For an opinion that while "education leads to large and statistically significant differences in earnings, these differences . . . are relatively small in comparison with those arising from the conglomeration of family background, 
In fact, the principal purpose of much education-law school, medical school, engineering or a cram course in preparation for a CPA exam-may be business rather than personal.

It is interesting that the IRS does not really deny this. The regulations state that the cost of education which is a prerequisite for obtaining the current position, or which qualifies the individual for another trade or business, represents an "inseparable aggregate of personal and capital expenditures," 94 and is thus not an ordinary and necessary business expense. This could be taken as an admission that some portion of such expenditures are business related and should, like the cost of a building, be amortized over the period of usefulness (perhaps to age sixty-five or over the period of like expectancy), ${ }^{95}$ but it does not appear that the Treasury has conceded that point. ${ }^{96}$ Instead, the Service could be suggesting that for education expenses to be deductible, the cost must exceed the personal benefit, and that all education prior to qualifying for a job has or is likely to have some personal benefit. Since the amount of this personal benefit cannot be established in a particular case, being "inseparable" from the capital expenditure, it follows that the amount of the business expense cannot be determined..$^{9 \tau}$ and no deduction is justified.

\section{Evaluation}

The question of a tax deduction for the cost of higher education is an enormously complex subject, involving not only the effort to perfect the definition of income with which this Article is concerned, but also such matters as the extent to which education should be subsidized, the effects of a tax allowance on the allocation of educational resources, and the redistribution of income or educational opportunity. This has been exhaustively studied elsewhere, ${ }^{98}$ and it would be presumptuous to do more than offer a few tentative conclusions here.

attitudes and nonpecuniary preferences and are no larger than the differences due to ability," see, Taubman, Personal Characteristics and the Distribution of Earnings (to be published).

${ }^{34}$ Treas. Reg. $\& 1.162-5(b)(i)$ (1967). This language, adopted in 1967, represents a change from the previous statement that disallowed expenses were personal. See Wolfman, Education, supra note 16 , at 546 .

${ }_{\text {gs }} C f$. Rev. Rul. 70-171, 1970-1 Cum. BuLl. 55 (fee paid by a physician for nontransferable lifetime privilege to use a hospital's facilities can be amortized over physician's life expectancy).

${ }_{96}$ See note 16 supra.

${ }^{97}$ The Service may also be suggesting that amortization is not allowable because a useful life cannot be established. Id.

${ }^{98}$ McNulty, supra note 25, passim. 
In general, there is little to criticize in present law. As to the deductions which are allowed, the likelihood of personal benefit from these expenditures is small enough to be reasonably overlooked. ${ }^{99}$ On the other side, since the personal benefit of education does not significantly conflict with its business use, it is possible for the personal value to equal the expense of education. The personal benefits at least through college seem fairly strong. If personal satisfaction is equal to cost, even the assumption of a large return on investment does not justify the deduction. Moreover, the strict position of the Internal Revenue Service is consistent with the proposition advanced here that doubt should be resolved by denying a deduction. Certainly, any increased tax burden caused by doing so will fall most heavily on relatively high-income persons.

Nevertheless, it is difficult to believe that all nondeductible educational expenses have enough of a personal element to justify the Treasury's approach. It is hard to find any personal satisfaction in a bar review course or in a course for preparation for the CPA exam. ${ }^{100}$ It would also seem that the personal content in vocational, paraprofessional, professional and perhaps other postgraduate education is minimal. ${ }^{101}$ It is also arguable that certain undergraduate courses, such as those in engineering or business, are primarily career related.

A distinction between types of undergraduate courses, however, would create insurmountable administrative problems. ${ }^{102}$ Moreover, at least among some groups, a college education may have become such a necessity for future personal relationships that it may be reasonably safe to assume that these technical courses are mere replacements for a liberal arts degree. Perhaps for the student they do not have as high a personal value as a major in an area like English would, but it is probably necessary to ignore this distinction. It is doubtful that there would be a large amount of error if it were assumed that all academic

${ }^{99}$ But see Keith W. Shaw, $28 \mathrm{CCH}$ Tax Ct. Mem. 626 (1969). The case holds that flying expenses of an FAA medical examiner, including cost of a refresher course, were deductible because they maintained or improved skills needed in determining whether pilots were medically able. The court suggested that it would have been immaterial that the taxpayer's principal purpose might be personal enjoyment. Id. at 631 .

100 But see Rev. Rul. 69-292, 1969-1 Cum. Bull. 84.

${ }^{10} \mathrm{See} \mathrm{McNulty}$, supra note 25 , at 18. Professor McNulty suggests that there is a personal benefit from this education, although presumably less than the amount obtained from an undergraduate program. The "purely personal delights of legal instruction" would include "the elevated social status of the legal profession, . . . bettered marital opportunities, ... daily classroom entertainment [and] generally sharpened intellectual powers."

${ }^{302}$ Wolfman, Education, supra note 16 , at 548 . 
education through college has a personal satisfaction equal to cost. It is very unlikely that the same could be said for a professional or other postgraduate course.

Therefore, it seems reasonable to allow a deduction (amortized over a working career) for the cost of postgraduate work and post-high-school vocational training. ${ }^{103}$ If one feels that some education of this type is significantly or even primarily for personal satisfaction, somewhat greater protection against abuse could be achieved by limiting any writeoff to earned income, or more strictly to the total income from the profession to which the education is ostensibly related. ${ }^{104}$

\section{B. Job-seeking and Other Preparatory Expenses}

\section{The Law}

Deductions have been denied for the cost of seeking out job opportunities, because the expenses were not related to the "carrying on" of the taxpayer's current trade or business but rather were intended to put the individual in a position to do the job. ${ }^{105}$ Thus, campaign expenses in seeking election or reelection to office are not deductible, ${ }^{106}$ but the cost of opposing a recall petition is. ${ }^{107}$

In an apparent exception to this rule, the Internal Revenue Service has always allowed a deduction for employment agency fees payment of which is contingent upon the agency placing the taxpayer in a job. ${ }^{108}$ The Service originally denied a deduction

${ }^{103}$ For views consistent with those expressed in the text, although apparently more receptive to a deduction for the cost of undergraduate college education, see McNulty, supra note 25, at 27-30, 31-32, 36; Wolfman, Education, supra note 16, at 548-50.

${ }^{104}$ See McNulty, supra note 25, at 30-31; Wolfman, Education, supra note 16, at 549.

105 The quote is from INT. REv. CODE of 1954, \$ 162. See generally Wilberding, $A n$ Individual's Business Investigation Expenses: An Argument Supporting Deductibility, 26 TAx LAw. 219 (1973). See also Treas. Reg. \$ 1.212-1(f) (1957).

${ }^{106}$ McDonald v. Commissioner, 323 U.S. 57 (1944); Vernon v. Commissioner, 286 F.2d 173 (9th Cir. 1961), affg Ernest H. Vernon, 18 CCH Tax Ct. Mem. 851 (1959) (union election). Cases like David J. Primuth, 54 T.C. 374 (1970), see note 111 infra, make it difficult to affirm the rule in McDonald on the ground that the expenses are not related to being an official, at least if it is a reelection campaign. The courts may continue to reach the same result on grounds of public policy, which was an alternative holding in McDonald. See James B. Carey, 56 T.C. 477 (1971), aff'd per curiam, 460 F.2d 1259 (4th Cir.), cert. denied, 409 U.S. 990 (1972); Horace E. Nichols, 60 T.C. 236 (1973). Since public office is sought for reasons other than the salary, campaign expenses may also be considered personal. In fact, the amount spent may often be well beyond what would be justified by the expected monetary return.

${ }^{107}$ Rev. Rul. 71-470, 1971-2 CuM. BuLl. 121.

108 O.D. 579, 3 Cum. Bull. 130 (1920) (allows deduction for "fees paid to secure employment"), revoked, Rev. Rul. 60-158, 1960-1 Cum. Buli. 140, reinstaled, Rev. Rev. 60-223, 1960-1 Cum. BuLl. 57 (allows deductions for fees paid "for securing employment"). See David J. Primuth, 54 T.C. 374, 380 (1970). 
for fees payable regardless of the agency's success, but this distinction has recently been withering away in a series of cases involving fees to Frederick Chusid \& Co. and similar agencies. Chusid offers a service to executives which includes an evaluation of the client's background, abilities, personality and opportunities, and assistance in developing material which will sell the client to prospective employers.

In David J. Primuth, ${ }^{109}$ the Tax Court permitted a deduction of the cost of the Chusid Agency's fee despite the fact that payment of the fee was not contingent on the securing of new employment. In cases like Primuth in which the taxpayer in fact secures a new job, the Internal Revenue Service has acquiesced in the result, ${ }^{110}$ but the Tax Court goes further and allows a deduction for fee-payers who do not find new jobs, thus rejecting the Service's distinction between seeking and securing employment. ${ }^{111}$

The court's focus now seems to be on whether the job being sought can be related to a trade or business in which the taxpayer is currently engaged. Some earlier cases had defined the taxpayer's trade or business quite narrowly in terms of employment with a particular company, ${ }^{112}$ but more recently the Tax Court has created categories of greater breadth, such as administrator or executive. ${ }^{113}$ This change in approach has not completely solved the problem, however. For example, an Air Force officer facing retirement was denied a deduction, because the job he was seeking was not related to the business of being an Air Force officer. The court failed to consider whether the new job would have utilized similar skills. ${ }^{114}$ In addition, there may still be a requirement that the taxpayer remain employed while looking for the new job, even if the job he seeks is in a field in

10954 T.C. 374 (1970).

110 Rev. Rul. 71-308, 1971-2 Cum. BuLl. 167 (distinguishes "seeking" from "securing" employment and makes clear that costs incurred while simply seeking employment, without securing it, are not deductible).

${ }^{111}$ Leonard C. Black, 60 T.C. 108, 113 (1973). The court stated: "It is now a settled proposition of law in this Court that expenses incurred in either seeking or securing new employment within the taxpayer's established field are deductible."

Following Primuth, the court first allowed a deduction when a new job was found even though it was not accepted, Kenneth R. Kenfieid, 54 T.C. 1197 (1970); then when the taxpayer failed to find a job, Leonard F. Cremona, 58 T.C. 219 (1972); and even though the taxpayer voluntarily terminated his relationship with the agency before it completed its efforts, Roy E. Blewitt, Jr., $31 \mathrm{CCH}$ Tax Ct. Mem. 1225 (1972).

${ }_{112}$ See, e.g., Thomas W. Ryan, $18 \mathrm{CCH}$ Tax Ct. Mem. 580, 582 (1959).

${ }^{113}$ Leonard F. Cremona, 58 T.C. 219, 222 (1972) (administrator); David J. Primuth, 54 T.C. 374,377 (1970) (corporate executive).

114 Eugene A. Carter. 51 T.C. 932 (1969). See Leonard F. Cremona, 58 T.C. 219,221 (1972). 
which he previously worked. ${ }^{115}$ Finally, with the exception of the revenue ruling allowing contingent employment agency fees to be deducted, there does not seem to be any support for a deduction for taxpayers who enter an entirely new business or profession. Thus, bar examination fees and other costs of admission to the bar continue to be nondeductible. ${ }^{116}$

\section{Analysis}

The courts have been able to justify the disallowance of job seeking and other preparatory costs by pointing out that at the time the expenses were incurred, the taxpayer was not yet "carrying on" a trade or business as required by section 162 of the Internal Revenue Code. This may be an acceptable distinction between current and capital expenditures, ${ }^{117}$ but it is difficult to see how it converts a business-related expenditure into a personal expense. ${ }^{18}$ As is true with education, this rather technical approach can be supported only if one believes that it is not practicable to determine the business purpose of an expenditure in the absence of a current activity to which the expense can be related.

The apparent discrepancy with respect to contingent agency fees may be explained by the Tax Court decision in Cecil Randolph Hundley, $J r^{119}$ Hundley, a major league catcher, was allowed a deduction for an amount paid to his father for creating the publicity and other circumstances which enabled Hundley to secure a bonus for signing a baseball contract. The court held that although Hundley was not in a trade or business when the services were performed, he was in a trade or business when the obligation became fixed, because liability depended upon the signing of a baseball contract. If this explanation is valid, it seems difficult to deny a deduction for the cost of admission to the bar (but not examination fees) which is payable only when the examination is passed, since at the time the obligation to pay

115 Miller v. United States, 73-2 U.S. Tax Cas. I 9681 (E.D. Tenn., Aug. 14, 1973); James Davis Protiva, 29 CCH Tax Ct. Mem. 1318, 1321 (1970). But See Gale Carlisle Huber, 29 CCH Tax Ct. Mem. 958, 960 (1970); David J. Primuth, 54'T.C. 374, 378 (1970); Harold Haft, 40 T.C. 2 (1963), acquiescing in result, 1967-2 Cum. Bull. 2 (unemployed salesman allowed cost of continuing to make contacts with former customers while seeking similar employment).

${ }_{116}$ Treas. Reg. \& 1.212-1(f) (1957).

117 See Richmond Television Corp. v. United States, 345 F.2d 901 (4th Cir.), rev'd on other grounds, 382 U.S. 68 (1965).

${ }^{118}$ Wolfman, Expense, supra note 16, at 1112.

${ }^{119} 48$ T.C. 339 (1967), acquiesced in, 1967-2 CuM. BuLl. 2. 
becomes fixed, the taxpayer will effectively have been accepted into the legal profession.

\section{Evaluation}

The decisions in this area seem overly restrictive in view of the minimal risk of personal satisfaction from these expenditures. If an individual claims that a trip to Las Vegas was for the purpose of looking for a job as a manager of a hotel, one is justifiably suspicious, even if the individual is now a manager of a hotel at an eastern resort. But the personal element in a newspaper advertisement or in a payment to the Chusid agency while seeking new employment is much harder to find.$^{120}$ It could only exist if the change in position was sought in order to permit a move to a more pleasant city rather than to further the taxpayer's career. This possibility should not result in disallowance when no change of residence is involved. Moreover, the statutory treatment of moving expenses suggests acceptance of the notion that most job changes are caused by a desire for advancement in one's business. ${ }^{121}$ Since the business benefit is relatively clear, while the possibility of deriving personal satisfaction from job-seeking costs not involving travel or education is so slight, these expenditures should either be deducted currently or amortized over the individual's working life.

\section{Clothing and Uniforms}

\section{The Law}

The current policy of the IRS with regard to uniforms and work clothing is still that set forth in 1950, when two conditions were established for deductibility: the clothing must be required as a condition of employment, and it must not be adaptable to ordinary wear. ${ }^{122}$

At an earlier time, the IRS had held that the cost of uniforms was personal, because uniforms merely replace ordinary clothing. ${ }^{123} \mathrm{~A}$ break in this position came in the late thirties when jockeys ${ }^{124}$ and baseball players ${ }^{125}$ were permitted deduc-

${ }^{120}$ See David J. Primuth, 54 T.C. 374, 379, 381 (1970).

121 INT. REv. CODE of 1954, \$ 217; see text accompanying notes 171-75 infra.

122 Mimeo 6463, 1950-1 Cum. Buzl. 29, superseded, Rev. Rul. 70-474, 1970-2 Cum. BuLl. 35.

${ }_{123}$ I.T. 1488, I-2 Cum. Bull. 145 (1922).

124 G.C.M. 19662, 1938-1 CuM. Bult. 118, superseded, Rev. Rul. 70-475, 1970-2 Cum. BULL. 35.

${ }_{125}$ G.C.M. 19790, 1938-1 Cuм. Bun. 118-19, superseded, Rev. Rul. 70-476, 1970-2 Cum. Bull. 35. 
tions. The rationale for this change eventually led to the issuance of the IRS' current position in $1950 .{ }^{126}$

The condition that no deduction be permitted for clothing which is suitable for off-the-job wear, or even for clothing which is not if the employer does not require it to be used, has been strictly enforced. Thus, a plastics worker confined to a wheelchair was denied deductions for a protective apron that was not employer required, and heavy work pants that were suitable for ordinary wear. ${ }^{127}$ Regular military personnel are not permitted to deduct the cost of their uniforms on the ground that they merely take the place of articles required in civilian life. ${ }^{128}$ The Treasury apparently assumed this clothing could be worn after hours, because it allows a deduction to reservists who can only wear uniforms while on duty. ${ }^{129}$ Whether clothing is actually worn outide of work is ordinarily immaterial. Thus, a California driving examiner was not allowed a deduction for the cost of his required grey suit because it was suitable for ordinary wear, despite the fact that it never was so used. ${ }^{130}$ However, it has been possible in some cases to establish that clothing is unsuitable for ordinary wear either because of the possibility of spreading disease encountered in the course of work, ${ }^{131}$ or because custom and usage forbid off-duty use. ${ }^{132}$

Actors have been treated more leniently. For example, Ozzie Nelson was permitted to deduct the cost of clothing worn on the TV show Ozzie and Harriet, despite the fact that what he wore was not noticeably different from what people wear generally. ${ }^{133}$ The other notable exception is Betsy Lusk Yeomans, ${ }^{134}$ who was permitted to deduct a small portion of the cost of the high fashion clothing required by her job as a fashion coordinator.

126 See also Rev. Rul. 59-219, 1959-1 Cum. Bull. 46-47.

${ }^{127}$ James Donnelly, 28 T.C. 1278 (1957), aff'd, 262 F.2d 411 (2d Cir. 1959). On appeal, Judge Hand in dissent objected to the use of the "employer requirement" test to deny a deduction for the apron. His position would sanction a deduction for any item unsuitable for ordinary wear which protects regular clothing while at work. 262 F.2d at 413. See also Rev. Rul. 57-143, 1957-1 Cum. Bull. 89 (painter's whites not deductible).

${ }^{12 B}$ Treas. Reg. $\S 1.262-1$ (b)(8) (1958).

129 Id. See also Rev. Rul. 67-115, 1967-1 Cum. BuLs. 30.

${ }^{130}$ Harry J. Sanner, 28 CCH Tax Ct. Mem. 476 (1969). But see Robert C. Fryer, 33

CCH Tax Ct. Mem. 122 (1974) (shoes worn by airline pilot).

${ }^{131}$ Oliver W. Bryant, 11 CCH Tax Ct. Mem. 430 (1952).

132 Rev. Rul. 67-115, 1967-1 CuM. Buls. 30 (military fatigue uniforms); Helen Krusko Harsaghy, 2 T.C. 484, 486 (1953), acquiesced in, 1945 Cum. Bul.. 3.

${ }^{133}$ Oswald G. Nelson, 25 CCH Tax Ct. Mem. 1142 (1966). See also Charles Hutchison, 13 B.T.A. 1187 (1928), acquiesced in, VIII-1 Cum. BulL. 22 (1929) (movie stuntman's clothing costs deductible due to heavy wear and tear).

${ }^{134} 30$ T.C. 757 (1958), acquiesced in, 1959-1 Cum. BuLl. 5. 


\section{Analysis}

It is often assumed that people who work spend more on clothes than those who do not. ${ }^{135}$ The suit the new lawyer wears to the office will cost more than the blue jeans he wore to class in law school. Yet, with the exception of uniforms and other equipment required by the employer which cannot be used off the job, no deduction is allowed.

Clothing and food, as essentials of life, are different from education, entertainment or travel. In the absence of business reasons it is easily conceivable that the last three items will not be purchased, but people will eat or wear clothes, regardless of whether they work. The clothes one wears to work may not be identical to what one would wear at leisure, but they are at least in part a substitute for leisure clothes. The fact that similar clothes can be, and probably are, worn off the job indicates that there is personal satisfaction from on-the-job wear. Moreover, one cannot assume that what an individual otherwise would have spent on clothes is an accurate measure of the value he attaches to the clothes he wears to work. Since this is true, it is probably correct to assume that the personal valuation is at least as great as the cost. Thus, although the employed person is spending more on clothes, he is also enjoying it more. This supports current law, which classifies most clothing costs as nondeductible personal expenditures.

The assumption is, however, unfair to anyone who attaches a personal valuation to on-the-job clothing which is less than the market price. For example, assume that over a given period Enough Business would spend $\$ 20$ on the clothing worn during the daytime period when most people are at work. Upon being employed, Enough needs to spend $\$ 50$ for work clothes for the same period. If perfect information as to value were available, the difference between $\$ 50$ and the personal satisfaction Enough attaches to these clothes should be a deductible business expense. Enough's personal satisfaction is not necessarily the $\$ 20$ he would otherwise spend. It could be more than $\$ 20$, if Enough would have been willing to spend more, say $\$ 30$, in order to buy these clothes, although he did not value them at the $\$ 50$ market price. In other words, even in the absence of the job, Enough would have been willing to transfer $\$ 10$ of his consumption from movies to clothes, if these particular clothes were available at $\$ 30$. On the other hand, Enough's personal satisfaction may be

${ }^{135}$ See R. GoODE, supra note 25 , at 81 . 
less than the $\$ 20$ he would otherwise spend, if he feels uncomfortable in the work clothes. ${ }^{136}$ An assumption of zero satisfaction would explain the rule relating to uniforms.

\section{Evaluation}

There are strong reasons for assuming that the personal satisfaction derived from clothing worn at work is equal to cost. Clothes, of course, must be worn whether or not the individual is working. If one is able to wear what one likes, there is not likely to be a significant decrease in satisfaction from the clothes because of the surroundings in which they are worn.

If work clothes wear out more quickly because of the nature of the work, or otherwise cost more, there is a justification for a deduction. The personal satisfaction from wearing a new pair of overalls each week can hardly be much greater than that which is derived from a single pair which lasts three months. The fact that their clothes could be worn only briefly may explain the relative leniency towards actors. ${ }^{137}$ Moreover, there are indications that the possibility that some uniforms are more expensive than regular clothing may have influenced the allowance of deductions. ${ }^{138}$ Nevertheless, neither excessive cost nor lack of durability seems to be a unique characteristic of uniforms, if they are indeed strong features at all.

A more likely explanation for the treatment of uniforms is that because they are not normally worn, one is less sure about personal satisfaction. Clearly, a space suit furnished to an astronaut does not produce personal benefits equal to its cost. But the rule seems too liberal in many cases. A policeman may feel just as good in a uniform as he would off duty in a suit. Certainly, it is not illogical to assume that he might value the uniform at least as much as the amount he is saving on the cost of civilian clothing.

Nevertheless, while a rule limiting a deduction to items which do not replace other clothing and to uniforms which are significantly more expensive than the civilian clothes replaced is logically more defensible, not enough is gained from this refinement to justify the extra administrative burden. This may be particularly true since most people who wear uniforms are

${ }^{136}$ Suppose that a young attorney hates wearing suits and ties so much that he would not pay even a penny to get them for personal use. In such circumstances, even though he may save $\$ 20$ on the cost of jeans it does not seem possible to say that he has $\$ 20$ of consumption from wearing suits.

137 See cases cited note 133 supra.

${ }^{138}$ See Marcus O. Benson, 2 T.C. 12 (1943), affd, 146 F.2d 191 (9th Cir. 1944). 
relatively low paid and may not be getting psychic benefits or other nontaxable fringe benefits from their jobs. In general, present law is acceptable.

\section{The Office in the Home}

\section{The Law}

Self-employed professionals have apparently never had any difficulty in obtaining deductions for the use of space in the home as an office. Thus, the regulations have stated since 1918 that:

A taxpayer who rents a property for residential purposes, but incidentally conducts business there (his place of business being elsewhere) shall not deduct any part of the rent. If, however, he uses part of the house as his place of business, such portion of the rent and other similar expenses as is properly attributable to such place of business is deductible as a business expense. ${ }^{139}$

The IRS and the courts have not insisted that part of the house be set aside exclusively for business. For example, in Imero $O$. Fiorentino ${ }^{140}$ the court permitted a TV lighting designer to deduct twenty percent of the cost of a four room apartment, because he used various parts of the apartment for business.

Employees have had a much more difficult time, as the IRS has insisted upon proof that the use of the home was specifically required by the employer. ${ }^{141}$ This condition has been gradually eroded. The early taxpayer successes mostly involved teachers who were able to deduct for an office in the home upon a showing of the nonexistence, inadequacy or inconvenience of employer supplied work space. ${ }^{142}$ More recent decisions have dispensed with the requirement of strict necessity and have allowed a deduction when the use of a home office by the employee was appropriate and helpful, regardless of the fact that it may also have been convenient. ${ }^{143}$

${ }^{139}$ Treas. Reg. $\$ 1.262-1(b)(3)$ (1958). Nearly identical language, except that it referred specifically to "professionals," appeared in T.D. 2831, 21 TREAS. DEC. INT. REv. 170,240 (1918) (Reg. 45, \& 291).

14029 CCH Tax Ct. Mem. 1445 (1970).

14 Rev. Rul. 62-180, 1962-2 Cum. Bull. 52.

142 Rev. Rul. 64272, 19642 Cum. Bull. 55; Clarence Peiss, 40 T.C. 78 (1963), acquiesced in, 1968-2 Cum. Butl. 2.

${ }^{143}$ See, e.g., LeRoy W. Gillis 32 CCH Tax Ct. Mem. 429 (1973); Marvin L. Dietrich, $30 \mathrm{CCH}$ Tax Ct. Mem. 685 (1971); George H. Newi, 28 CCH Tax Ct. Mem. 686 (1969), aff'd, 432 F.2d 998 (2d Cir. 1970). 
The liberality of the Internal Revenue Service in agreeing to deductibility for the self-employed has been offset by its strictness in computing the amount of the deduction in circumstances where space is not exclusively set aside for business. Once the applicable cost of the relevant portion of the house is determined, the Service asserts that the amount deductible should depend upon the percentage of business use as compared to total hours in the day. ${ }^{144}$ Taxpayers, on the other hand, have claimed that the denominator of the fraction should be only the total amount of actual use. This was recently accepted by the Tax Court in George W. Gino. ${ }^{145}$

\section{Analysis}

The current approach to a deduction for an office in the home seems designed to allow a deduction whenever there is a business justification for the expenditure. This could explain the IRS attempt in the case of employees working in the home, to apply a stricter definition of "necessary" than the usual test, i.e., whether an expenditure is appropriate and helpful. ${ }^{146}$ Since there may be personal reasons for securing the space which is claimed to be a home office, the Service is seeking more assurance that the business benefit is worth the cost. ${ }^{147}$ One sympathizes with the Treasury, but it must be noted that a similar uncertainty as to business benefit exists with respect to the self-employed or even where the employer requires a home office. ${ }^{148}$

There may also be an implicit assumption that the total personal and business valuation which can be placed on a particular room is no greater than the rent or other applicable costs.

${ }^{144}$ Rev. Rul. 62-180, 1962-2 Cum. Bull. 52, 56-57. This position was approved in Hoggard v. United States, 67-2 U.S. Tax Cas. I 9741 (E.D. Va. 1967); Martha E. Henderson, 27 CCH Tax Ct. Mem. 109 (1968).

${ }^{115} 60$ T.C. $304,314-15$ (1973).

${ }^{146}$ See Wolfman, Expense, supra note 16 , at 1105.

147 See Robert Lee Henry, 36 T.C. 879, 884 (1961); Wolfman, Expense, supra note 16, at 1107. The IRS maintains a similar position with respect to clothing used on the job, and previously insisted that education could be deducted only if required by the employer. See text accompanying notes 122-27 supra (clothing); note 71 supra (education). See generally INT. REv. CODE OF 1954, § 119(2) (allowing exclusion from income of the value of lodging where "the employee is required to accept such lodging . . . as a condition of his employment"); Lee, supra note 6 . The Tax Court, in rejecting the Internal Revenue Service's position relative to the home office, has suggested that the "requirement of the employer" test has been rejected in other areas, including clothing. Marvin L. Dietrich, $30 \mathrm{CCH}$ Tax Ct. Mem. 685, 686-87 (1971).

${ }^{148}$ In other circumstances, the IRS has disavowed any intent to discriminate against employees as compared to the self-employed. Treas. Reg. \$1.162-2(d) (1958); Wolfman, Expenses, supra note 16, at 1101-03. 
Therefore, as is the case with an automobile, the division between personal and business values can be determined on the basis of relative use. ${ }^{149}$

\section{Evaluation}

There should be a deduction for office space in the home where a particular room is used exclusively, or nearly so, for business purposes; but where space is used partly for business and partly for personal purposes, the present approach understates taxable income. It is surprising, in light of the very real doubt as to the business benefit, that it is not required that the principal purpose of the room be for business. Also being ignored is the real possibility that despite business use, the personal satisfaction from the room may not be less than cost. Although the potential conflict between business and personal use can be greater with a room in the house than it is with clothing or education, it is doubtful that the conflict is as great as it is with an automobile, so as to justify unquestioning adoption of the same approach.

Thus it seems unlikely that many people would assert the right to deduct ten percent of the basic telephone charge because ten percent of their monthly calls were business related. ${ }^{150}$ This is correct, because they probably would have had the phone installed in any event, and the personal valuation of the phone service is at least equal to the basic charge despite the interference of the business calls. Nevertheless, many people deduct part of the cost of their living quarters even though their house is the same size as it would be in the absence of an office in the home. ${ }^{151}$ How many of these people could say that while the house would provide personal satisfaction equal to cost in the absence of the office, it now falls short because the existence of the office diminishes the personal use? Is it not possible that there are people who get full value from both the business and the personal use of the room, or at least that the dual use adds to the value of the room so that personal satisfaction is not diminished by the full amount of business benefit?

The IRS method, limiting the deduction to that percentage of the cost of the space which reflects the ratio of business use of the space to its total availability, could be supported if one

149 See text accompanying note 57 supra.

${ }^{150}$ But see Martha E. Henderson, 27 CCH Tax Ct. Mem. 109, 112-13 (1968).

${ }^{151}$ See Stephen A. Bodzin, CCH TAX CT. Rep. No. 32,115 at 2933 (1973) (Featherston, $J$, dissenting). 
assumed the acquisition of the space was justified personally, but the personal satisfaction was reduced because during a certain number of hours the room was unavailable for nonbusiness purposes. This approach is too generous if the business use (weekday evening) does not interfere at all with the personal use (guest room for weekends), but may be too restrictive if, for example, the placing of the furniture interferes with personal use. However, it seems a reasonable compromise.

In sum, where the principal purpose of acquiring the space in question is personal, a deduction should be denied. Although comparative use is not an absolute measure of whether business or pleasure is more important, it is close enough to warrant taking advantage of the availability of an objective test. Where the primary use is business, a deduction should be permitted, preferably applying the ratio of actual business use to total availability. This may be hard to support when personal use is not substantial. After all, if business use is exclusive, a full deduction is allowed even though the room is not used twenty-four hours a day. Should there be such a dramatic change when there is' one percent personal use? Nevertheless, because the business benefit may be doubtful and the personal satisfaction seems so strong, it would probably be justifiable, on account of the view that it is better to err on'the side of disallowance-to adopt the IRS rule-at least whenever the personal use is significant. In fact, for the same reason total disallowance is probably appropriate whenever personal use is significant.

\section{E. Travel Fares}

\section{The Law}

This section will focus solely on the costs of transportation; meals and lodging will be discussed separately. A taxpayer's right to a deduction for fares depends upon the business reason for the trip. Stricter rules apply to travel as a form of education and to travel to seek out new job opportunities. It is also more difficult to get a deduction if the trip takes the taxpayer outside the United States.

\section{a. In General}

If a trip is exclusively for business, travel fare is a deductible expense. ${ }^{152}$ If while at a destination a taxpayer 
engages in both business and personal activities, traveling expenses to and from such destination are deductible only if the trip is related primariily to the taxpayer's trade or business. If the trip is primarily personal in nature, the traveling expenses to and from the destination are not deductible even though the taxpayer engages in business activities while at such destination. ${ }^{153}$

The regulations state that the primary purpose of a trip is to be determined from all the facts and circumstances, but that the amount of time spent on business as compared to personal matters is an important factor to be taken into account. ${ }^{154}$

\section{b. Education and Travel}

Travel primarily to take a course is deductible if the education involved is the kind for which a deduction is allowed. ${ }^{155}$ Primary purpose is determined in the manner just described for business travel generally. Travel will also be deductible as a form of education in itself, if the taxpayer can show that the major portion of his activities during a period of travel is of a nature "which directly maintains or improves skills required by the individual" in his business. ${ }^{156}$ Most of the taxpayers who have sought to take advantage of this opportunity have been teachers. Although many have been unsuccessful, ${ }^{157}$ others have persuaded the judge that the travel expenses contributed to the enhancement of the taxpayer's teaching skills. ${ }^{158}$

\section{c. Change of Jobs}

The Internal Revenue Service has held that an individual does not obtain income from an all-expense-paid trip to visit a prospective employer. ${ }^{159}$ Conversely, the Service considers the

${ }^{153}$ Treas. Reg. § 1.162-2(b)(1) (1958).

${ }^{154}$ Treas. Reg. $\S 1.162-2(\mathrm{~b})(2)(1958)$.

155 Treas. Reg. \& 1.162-5(e) (1967).

${ }^{156}$ Treas. Reg. $\$ 1.162-5$ (d) (1967). This rule is made subject to the provisions of Treas. Reg. $\$ 1.162-5(\mathrm{e})$, which requires that the primary purpose of the trip be business. However, since the 1967 amendments to this regulation, T.D. 6918, 1967-1 CuM. Bull. $36,39-40$, the courts have stated that the subjective test (motive for the trip) is no longer applicable to travel as education. See, e.g., Krist v. Commissioner, 483 F.2d 1345, 1348 (2d Cir. 1973); Stanley Marlin, 54 T.C. 560,565 (1970), acquiesced in, 1970-2 Cum. BuLL. xx. The Tax Court suggests that the objective test (allocation of time) is more liberal than the previously applicable subjective test, but this need not be true if a taxpayer can establish his primary motive was business related despite the fact that he spent more time on fun.

${ }_{157}$ See, e.g., Krist v. Commissioner, 483 F.2d 1345 (2d Cir. 1973); George W. Gino, 60 T.C. 304 (1973); James L. Denison, 30 CCH Tax Ct. Mem. 1074 (1971).

${ }_{158}$ See, e.g., Paul R. Dougherty, 29 CCH Tax Ct. Mem. 186 (1970); Gladys M. Smith, $26 \mathrm{CCH}$ Tax Ct. Mem. 1281 (1967); Helen V. Oehlike, $26 \mathrm{CCH}$ Tax Ct. Mem. 663 (1967).

${ }^{159}$ Rev. Rul. 63-77, 1963-1 CuM. BuLl. 177. 
cost of a trip in search of employment or to investigate a business or an investment opportunity nondeductible. ${ }^{160}$ Nevertheless, once a taxpayer has proceeded beyond mere investigation and has taken concrete steps to develop an investment opportunity, a loss will be deductible even though the transaction is never consummated. ${ }^{161}$ Moreover, in light of the recent liberalization in the area of employment agency fees, ${ }^{162}$ prior holdings may no longer be applicable to the extent a deduction has been denied on the theory that travel to seek new employment in the same field is not related to a current trade or business.

Closely akin to travel to another city in search of a job opportunity is the expense of moving once a job is obtained. The law is more liberal in this regard, however, as section 217 now allows the direct costs of moving family and furniture to be deducted. ${ }^{163}$ It also permits a limited deduction for the cost of a trip for the principal purpose of searching for a new residence. ${ }^{164}$ But, consistent with the job-seeking cases, the cost of a trip to seek a new residence is not deductible unless it is initiated after a job has been found.

\section{d. Foreign Travel}

Since 1962, under section 274 (c) of the Code, there have been further restrictions on deductions for foreign travel when the trip lasts more than one week and when the individual spends twenty-five percent or more of the trip's time engaged in nonbusiness activity outside of the United States. ${ }^{165}$ A portion of the fare is disallowed corresponding to the percentage that the number of nonbusiness days bears to the total days spent on the trip. ${ }^{166} \mathrm{~A}$ day is deemed entirely a business day, even though only spent partially on business, if the principal activity during

${ }^{160}$ Morton Frank, 20 T.C. 511 (1953); Rev. Rul. 70-396, 1970-2 Cum. Bull. 68. Cf. Rev. Rul. 57-418, 1957-2 Cum. Bull. 143.

${ }_{161}$ Theodore R. Price, 30 CCH Tax Ct. Mem. 1405-3 (1971); Harris W. Seed, 52 T.C. 880,887 (1969), acquiesced in, 1970-2 Cum. BuLl. xxi; Rev. Rul. 71-191, 1971-1 CuM. BuL... 77.

${ }_{162}$ See text accompanying notes 109-11 supra.

${ }^{163}$ INT. REV. CODE OF 1954, \& 217(b)(1)(A), (B).

${ }^{164}$ Id., $\& 217(\mathrm{~b})(1)(\mathrm{C})$. The Code sets a $\$ 1,000$ maximum on the total of such expenses and the sum spent on meals and lodging while occupying temporary living quarters at the new job location. It also establishes an overall $\$ 2,500$ limit for the total of expenditures subject to the $\$ 1,000$ limit plus the amounts spent to sell or buy a home or to acquire or terminate a lease. Id. \& 217(b)(3)(A).

${ }_{165} I d$. \& 274(c)(2). Section 274(c), which is derived from President Kennedy's 1961 recommendations, Hearings, supra note 8 , at 283-84, originally applied to all travel but it was restricted to foreign travel by the Revenue Act of 1964, Pub. L. No. 88-272, 78 Stat. $19,56$.

${ }_{166}$ Treas. Reg. \& 1.274-4(f)(1) (1964). 
business hours was the pursuit of a trade or business. Even if this condition is not met, it is still a business day if the taxpayer can show that his presence outside the United States was required on that day for a specific and bona fide business purpose, such as a particular meeting. ${ }^{167}$

However, the entire foreign travel expense will be allowed if the taxpayer can show that he did not have substantial control over arranging the trip, or that obtaining a vacation was not a major consideration in making the trip. ${ }^{168}$ Apparently, any employee who is not a ten percent shareholder will not be considered to have substantial control over a trip paid for by the employer, unless he "is authorized, without effective veto procedures, to decide upon the necessity for his business trip . . . ."169

\section{Analysis}

Present law focuses on the business benefit to be derived from a trip, allowing a deduction whenever such benefit is shown by the fact that the trip's principal purpose was business. Only in the case of travel as education do the regulations explicitly require that a major portion of the time be spent on business, although they do indicate that time spent will always be an "important" factor in determining principal purpose.

An exception to this approach is the reluctance to allow the cost of traveling to seek new employment to be deducted, regardless of whether there is a personal reason for the trip. As previously discussed, this may be explained by the fear that it will not be possible to discern the existence or absence of the business benefit when there is no current activity to which the trip relates. ${ }^{170}$ But if a prospective employer is willing to pay for the trip, this could establish a business purpose sufficient to justify the exclusion that is allowed.

In contrast to the restrictions on job-seeking costs, moving expenses receive liberal treatment. The Internal Revenue Code allows moving expenses to be deducted with only minimal consideration of the primary purpose of the move. ${ }^{171}$ The individual must work full time in the new location for at least thirty-nine

${ }^{167}$ Treas. Reg. $\$ 1.274-4$ (d)(2)(ii), (iii) (1964).

${ }^{168}$ Treas. Reg. \& $1.274-4(\mathrm{f})(5)(1964)$.

${ }^{160}$ Treas. Reg. \& 1.274-4(f)(5)(i)(a) (1964).

${ }^{170}$ See text accompanying notes $90,117-18$ supra.

${ }^{171}$ See R. Goode, supra note 25 , at $79-80$. Presumably, there is a willingness to assume that most job changes are career motivated and are not due to a personal desire to live in a different location. 
weeks during the year following the move, ${ }^{172}$ which makes it more difficult to deduct the cost of a move to a place selected as a retirement home. The requirement that the new job be fifty miles farther from the old home than the prior job ${ }^{173}$ helps assure that the move is connected with a job change. ${ }^{174}$ Nevertheless, there is little assurance that the job change did not occur because the taxpayer and his family preferred living in the new location. In fact, the move can take place even before a new job is found. Prior to 1962, no deduction was allowed in any circumstance. Exclusion from income of employer-paid moving costs was permitted only when the employer's willingness to pay and the absence of a change in employers tended to establish that the move was for the employer's purpose and not to enhance personal satisfaction. ${ }^{175}$

The allocation rules of the 1962 Revenue Act $^{176}$ treat travel costs similarly to the expense of an automobile in that it is assumed that total benefit cannot exceed cost, and that a good indication of the relative business and personal satisfactions is the time spent on each.

\section{Evaluation}

The guidelines presented in Part III are conflicting indicators as to the proper treatment of travel expenses. Since one can go to a destination, complete one's business, and then enjoy a vacation without any business interference, it seems more likely than with almost any other type of expenditure considered in this Article (except perhaps education) that the personal benefit from travel could be worth the full cost. On the other hand, unlike wearing clothing or eating, travel may be forgone in the absence of business considerations. Moreover, compared to entertainment, for example, there will be many more cases where travel will not provide any personal benefit at all. Certainly, some travel expense must be deductible.

${ }^{172}$ INT. REV. CoDE of $1954, \S 217(c)(2)$. For the self-employed the requirement is 78 weeks in the 2 years following the move.

${ }^{173}$ Id. \$ $217(\mathrm{c})(1)(\mathrm{A})$. (1972).

${ }^{174}$ For an example where this would not be so, see Treas. Reg. $\S 1.217-2(a)(3)(i)$

${ }^{175}$ Rev. Rul. 54-429, 1954-2 Cum. Bull. 53. The Tax Court rebelled at the dichotomy between deduction and exclusion and in several cases allowed deductions to employees who established that they moved for the convenience of the employer or to avoid losing their job. The courts of appeals, however, backed the Commissioner's view. See, e.g., Edward N. Wilson, 49 T.C. 406 (1968), rev'd, 412 F.2d 314 (6th Cir. 1969).

${ }^{176}$ Revenue Act of 1962, Pub. L. No. 87-834, 76 Stat. 960. 
Therefore, despite the lack of theoretical support for it, allocation as now required for certain foreign travel is probably the most reasonable approach to all travel expenditures. There is no reason this cannot also be applied to trips in search of a new job or business opportunity. "[T]ravel, in search of employment is as much an expense of carrying on the taxpayer's trade or business as is the expense of a manufacturer who sends a salesman in search of orders." 177

Some protection against the allowance of even a partial deduction when personal satisfaction is equal to cost could be achieved by retaining the present principal purpose requirement. This test should be made objective by looking to how the taxpayer spends his time. Not only will this reduce the incentive for exaggeration or outright cheating, but it will also tend to assure greater taxpayer acceptance of case-by-case results. ${ }^{178}$

Nevertheless, one has the uneasy feeling that the personal satisfaction from many trips, during which a majority of time could be said to be spent on business, will be equal to cost. This is particularly true of such practices as attending conventions in resort cities (especially when a desire to hold down costs would not dictate the chosen site which may be far from the homes of most of the participants), ${ }^{179}$ travel for education purposes ${ }^{180}$ and lecture cruises. ${ }^{181}$ In these situations, business needs such as the location of a particular customer do not determine the destination. In contrast, it is selected by either the taxpayer himself, a group to which he belongs, or a promoter with the recreational desires of the participants clearly in mind. If under present law a trip to Pittsburgh ${ }^{\mathbf{1 8 2}}$ in search of a business opportunity is suspect, how can a deduction be allowed for a trip to London by lawyers attending the convention of the American Bar Association?

177 Bittker, supra note 36 , at 1167 .

${ }^{178}$ See Klein, supra note 20 , at 1111 .

179 It is not even necessary for the convention's agenda to deal with matters within the taxpayer's duties and responsibilities. Rev. Rul. 63-266, 1963-2 Cum. BuLl. 88. For a warning against pushing one's luck too far, however, see T.I.R. 1275 (Feb. 14, 1974).

180 In one Tax Court case a world hictory teacher was allowed a deduction for a tour of France, while her husband, a Latin teacher, was unsuccessful. Stanley Marlin, 54 T.C. 560 (1970), acquiesced in, 1970-2 Cum. Bull. xx. While it may be true that the trip had more of a relation to the wife's work, one suspects that the result is not a fair reflection of the personal satisfaction each derived. See also John C. Ford, 56 T.C. 1300 (1971), affd per curiam, 487 F.2d 1025 (9th Cir. 1973) (taxpayer allowed a deduction for travel, meals and lodging in connection with enrollment in a Ph.D. program in Norway; no evidence offered as to reasons for not going to school in the United States).

${ }^{181}$ For an indication that the Service is concerned about abuse in this area, see T.I.R. 1275 (Feb. 14, 1974).

${ }^{182}$ Morton Frank, 20 T.C. 511, 512 (1953). 
An additional problem is distinguishing between the business and pleasure components of a trip. The IRS rules are too liberal in counting as a full business day any in which a majority of the normal working hours are spent on business, or in which any business meeting is held which the taxpayer is required to attend. The regulations also count weekends and other reasonably necessary standby days as business days when business is conducted before and after the weekend. In such circumstances the out-of-town stay may well be compelled by business reasons and in some cases will not provide any personal satisfaction. However, it is unnecessary to be so careful to avoid the possibility that someone will be charged with personal satisfaction he did not in fact enjoy.

An allocation rule should be adopted which would in all cases, regardless of the taxpayer's control over the trip ${ }^{183}$ or his purpose to obtain a vacation, permit a deduction only for a portion of the travel fare in the same proportion to the entire cost as time actually spent on business bears to the total time of the trip. For the purpose of computing the denominator of this fraction, it would be sufficient to consider a day to have only eight hours. An exception to the allocation rule could be provided when a trip takes only two or three days or if ninety percent or more of this time is spent on business. It should also be determined whether the more likely abuses can be sufficiently isolated so as to permit the total denial of a deduction in such circumstances.

The moving expense rules may be more liberal than this proposal. However, since they are not subject to manipulation to obtain tax-free recreation, it does not appear necessary to recommend a change at this time.

\section{F. Food}

\section{The Law}

There are circumstances in which a taxpayer can exclude from income the value of food he consumes, or deduct the cost of food if he has paid for it himself. Under the Code, the value of meals consumed on the employer's business premises, furnished for the convenience of the employer, is not taxable. ${ }^{184}$

${ }^{183}$ See J. Hellerstein, Taxes, Loopholes and Morals $141-42$ (1963).

184 INT. REv. CoDE of 1954, § 119. For unexplained reasons the Service continues to sanction the exclusion of "supper money" from income although the meal is not consumed on the employer's business premises. O.D. 514, 2 CuM. BuLL. 90 (1920). 
Also, a deduction is allowed for the cost of meals purchased while one is away from home overnight in the pursuit of a trade or business. ${ }^{185}$ The original administrative position was to allow as a deduction the extra cost of such meals over what would have been spent at home. ${ }^{186}$ However, the Service concluded very soon that this was unadministrable, and asked that the statute be amended to allow the entire cost to be deducted. ${ }^{187}$

If the trip is primarily for business, generally its entire cost, including the cost of meals on interim nonbusiness days such as weekends, is deductible. However, if extra time is taken for a vacation at the beginning or end of a trip, then the cost of meals for the extra period is not deductible. ${ }^{188}$ Even if the trip away from home is primarily personal so that travel fares are not deductible, expenses while at the destination "properly allocable to the taxpayer's trade or business," including meals, are deductible. ${ }^{189}$

There is a long standing dispute over what is meant by "away from home." The Service asserts that a taxpayer's home is his principal place of business, ${ }^{190}$ but some courts insist that the word must be given its normal everyday meaning. ${ }^{191}$ However, since most persons whose home is not located near their principal business location would, while working, be considered to be away from home for personal rather than business reasons and therefore denied a deduction, "in the overwhelming bulk of cases" 192 the results would be the same. This is particularly true since the Service agrees that a temporary change in business location, generally for less than one year, does not change one's principal place of business. ${ }^{193}$ Failure to move in such circum-

185 INT. Rev. Code of 1954, § 162(a)(2). See United States v. Correll, 389 U.S. 299 (1967). The overnight rule may not be strictly enforced. Certainly no one fails to deduct that portion of an airline ticket for a one day trip which is applicable to the meals consumed in Hight.

${ }^{186}$ T.D. 3101,3 Cum. Bull. 191 (1920), amending Treas. Aeg. 45, § 292 (1918).

${ }^{187}$ See United States v. Correll, 389 U.S. 299, 301 n.6 (1967). The change came in 1921. See Revenue Act of 1921, § 214(a)(1), 42 Stat. 239. Since 1962 there has been a specific prohibition against a deduction for expenditures which are lavish or extravagant under the circumstances.

${ }^{188}$ Rev. Rul. 56-168, 1956-1 Cum. Bull. 93; S. ReP., supra note 10, at 34; $c f$. Treas. Reg. $\$ 1.162-5(\mathrm{e})(1967)$. The allocation rules applicable to certain travel under $\$ 274$ (c) could result in a disallowance of part of the cost of meals consumed while in travel status. Rev. Rul. 63-144, 1963-2 Cum. Buls. 129, 142 q. 86.

${ }^{189}$ Treas. Reg. § 1.162-2(b)(1) (1958).

180 Rev. Rul. 60-189, 1960-1 Cum. BuLl. 60, 61. The Supreme Court has accepted this approach as to military personnel. Commissioner v. Stidger, 386 U.S. 287 (1967). 864 (1971).

${ }^{19}$ See, e.g., Rosenspan v. United States, 438 F.2d 905 (2d Cir.), cert. denied, 404 U.S.

192 Id. at 911. See Commissioner v. Flowers, 326 U.S. 465 (1946).

${ }^{193}$ Rev. Rul. 60-189, 1960-1 Cum. Bul.. 60. 
stances would not be deemed the result of personal choice. ${ }^{194}$ Therefore, persons who have temporarily relocated are away from home under either approach if they are living apart from their families. It is not yet clear.whether the courts which apply the normal meaning to "home" would consider the taxpayer to have moved if his family goes with him to the temporary location. ${ }^{195}$ The Service apparently allows a deduction even if the entire family moves.

One can also deduct the cost of meals, even though the taxpayer is not away from home, if consumed in a business context such as a lunch with a client or a testimonial dinner whose primary purpose is business. ${ }^{196}$ The IRS states that only the cost in excess of what would normally be spent should be deductible. ${ }^{197}$ However, despite the absence of a statutory rule as in the away-from-home area, the IRS has for administrative convenience generally allowed the full deduction. This is apparently so even, for example, when a lawyer has lunch with a client at the same restaurant in which the lawyer ate the previous day with an old friend, although the Service reserves the right to apply the correct rule in cases of "abuse." 198

\section{Analysis}

Although everyone is going to eat whether or not he works, experience indicates that people who work and therefore must eat outside the home often spend more on food than those who do not. Clothing presents a similar problem. However, there is a willingness to assume that the additional cost of clothing is accompanied by a like increase in personal satisfaction or, at least, that it is better to presume that value equals cost rather than undertake the task of ascertaining the amount of any difference. This same reasoning explains the denial of a deduction for the cost of lunch in a restaurant made necessary, or at

${ }^{194}$ See Rosenspan v. United States, 438 F.2d 905, 912 (2d Cir.), cert. denied, 404 U.S. 864 (1971).

${ }_{195}$ See Six v. United States, 450 F.2d 66, 69 (2d Cir. 1971). If the taxpayer is considered to have moved then the cost of transporting himself and his family would be a moving expense and not a travel expense. See Treas. Reg. \& 1.217-2(c)(3)(iii) (1972).

196 Rev. Rul. 63-144, 1963-2 Cum. BuLl. 129, 135.

197 The Tax Court reached this result in Richard A. Sutter, 21 T.C. 170, 173 (1953), acquiesced in, 1954-1 CuM. Bul.l. 6.

${ }_{188}$ According to Rev. Rul. 63-144, 1963-2 Cum. Bull. 129, 135, "abuse" means attempting to deduct a substantial amount of personal living costs. The Second Circuit, while prepared, following Richard A. Sutter, 21 T.C. 170 (1953), to deny a deduction for the cost of the taxpayer's own lunch at a hospital cafeteria, permitted the taxpayer on remand "to press his claim ... that this case does not fall into [the abuse] category." La Forge v. Commissioner, 434 F.2d 370 (2d Cir. 1970). 
least appropriate, by the fact that one is away from home during the noon hour because of work.

However, the away-from-home and convenience-of-employer doctrines take a different approach. Since circumstances compel the individual to eat where he might not choose to eat if given a free choice, it seems reasonable to assume that the taxpayer may not obtain satisfaction equal to the full cost of the meal. Rather than overtax the employee by assuming benefit equal to cost, or undertake the burden of determining the amount the individual would be willing to pay for the meal if not subject to business compulsion, the Code allows a full deduction or exemption. This is similar to the treatment of uniforms, which are also assumed to provide no personal satisfaction.

\section{Evaluation}

In the case of college, professional education or business clothing, the general approach is to deny any deduction despite the possibility that personal benefits may not equal cost. Food should be treated in a similar manner. Because of the substitution for other meals, the existence of some personal satisfaction is almost certain. Since, in many instances, one can enjoy a meal in a business setting as much as otherwise, such value probably approaches cost. ${ }^{199}$

It is true that the tax treatment of meals away from home affects relatively few people and the consequences of an exaggeration of satisfaction could be seriously inequitable. This is particularly true since the more meals one eats away from home, the more likely. it is that a low value will be attached to such meals. On the other hand, those who can deduct a large portion of their food costs have an extreme advantage, particularly in light of the assumption under the present law of no personal satisfaction at all.

This advantage may result from there being no extra cost at all for a business meal. As stated above, the taxpayer may eat in the same restaurant whether the lunch is business or personal. A Yale professor spending a year visiting at Harvard may eat his meals in Cambridge at home with his family at the same cost he would have in New Haven. ${ }^{200}$ Moreover, although one spends

${ }^{199}$ But see Hearings, supra note 8, at 1614 (testimony on behalf of National Restaurant Association to the effect that people do not enjoy business meals).

${ }^{200}$ See Lester E. Wood, 17 CCH Tax Ct. Mem. 976 (1958). Taxpayer moved from. job site to job site in a trailer in which he lived with his wife. Although costs were identical, at one job site he was considered to be away from home while at another he was not. 
more while away from home, satisfaction may well increase by a like amount.

Even if the law could be amended to identify more accurately those cases where personal satisfaction is likely to be unequal to the amount expended, it would still be inequitable to deduct the full cost whenever any excess expenditure exists. Administrative convenience may justify such a rule when there is an occasional business meal, but the result is outrageous when the Yale professor can deduct the entire cost of his food for a year.

To avoid these inconsistencies, there should be a complete denial of deductions for the cost of food. As a less drastic alternative, there should be an attempt to identify the extra cost of business meals which may be unlikely to increase the satisfaction over that which is obtained from eating at home. For example, suppose an ordinary dinner would cost $\$ 3$ at home, while a similar meal in a "simple" restaurant costs $\$ 10$. If an individual were eating dinner out solely for business reasons, it would be reasonable to assume that the extra $\$ 7$ does not increase consumption. On the other hand, a $\$ 25$ meal is likely to be more elaborate than the usual dinner at home. It is possible, of course, that a person would prefer to eat the simpler meal with his family and would, in the absence of business compulsion, pay nothing for the fancy dinner. Still, it is much closer to the truth to assume that at least the extra cost of a luxury meal produces personal satisfaction, than to conclude that there has been no personal benefit. It would be logical, under these assumptions, to permit a deduction for all costs in excess of $\$ 3$ up to $\$ 10$ for dinner. For simplicity, this could be converted into a uniform maximum deduction of $\$ 7$ per dinner. ${ }^{201}$ To give greater assurance that deductible costs are those due to a change in living pattern caused by travel away from home, no deduction should be allowed except for restaurant meals, ${ }^{202}$ and then only

${ }^{201}$ President Kennedy's 1961 proposals are consistent with this suggestion. He recommended a ceiling of $\$ 4$ to $\$ 7$ per day for the cost of meals while at home, and a maximum deduction for food and lodging while away from home equal to twice the per diem allowance for government employees. Hearings, supra note 8, at 283-84. At that time the government per diem allowance was $\$ 12$ per day with an increase to $\$ 15$ having been proposed. Id. The current amount for travel in the United States of $\$ 36$ per day, Standardized Government Travel Regulations, July 1, 1972, is a closer approximation of reality and a deduction for double that amount would seem unnecessarily generous. $C f$. Rev. Rul. 72-508, 1972-2 Cum. Bull. 200 (employee is considered to have accounted to employer for expense allowance if amount does not exceed $\$ 36$ per day or per diem rate authorized by federal government in the particular locality). Previously $125 \%$ of the federal per diem rate met this test, as did a maximum of $\$ 25$ per day, although the per diem rate was \$16. Rev. Rul. 65-212, 1965-2 Cum. Bulu. 84.

${ }_{202}$ An exception could be provided for an individual who has two jobs and lives with 
for breakfast and dinner since lunch is often eaten outside the home. Section 119 should be amended to limit the exclusion to the amount that would be deductible under section 162 for meals while away from home.

\section{G. Lodging}

\section{The Law}

Cost of lodging while away from home in pursuit of a trade or business is deductible in those circumstances in which meals are deductible. ${ }^{203}$ Similarly, lodging costs can be excluded from income under section 119 of the Code if the lodging is provided for the convenience of the employer, and the employee is required to accept lodging on the employer's business premises as a condition of employment. ${ }^{204}$

\section{Analysis}

An individual will not derive any personal satisfaction from an ordinary hotel room if he has no personal interest in a visit to the location to which he is traveling on business. However, if the taxpayer desires to travel to the city in question for recreation, sightseeing or visiting relatives, he has obtained some consumption which current law tends to overlook.

If an individual has no other living quarters available, it is likely that he will obtain some satisfaction from lodging on the employer's premises or away from home. However, because of the restrictions imposed by a temporary change of location, the Yale professor visiting at Harvard for a year may be forced to pay more for housing than he would if he were permanently located in the Boston area. Moreover, living on the employer's premises, particularly in an institutional setting, may not provide personal satisfaction equal to cost. In these circumstances, since the satisfaction is probably less than cost, the assumption is made that there is no personal benefit. ${ }^{205}$

his family at the secondary job location. The Service would allow a deduction for the costs of living at home. Rev. Rul. 55-604, 1955-2 CuM. BuLl. 49. This is legitimate, because this taxpayer does eat a substantial number of nondeductible meals in a restaurant at the primary location, and if the family moved to the primary business location, the individual would probably eat in a restaurant while at the secondary location.

${ }^{203}$ INT: REv. CODE OF 1954, § 162(a)(2).

${ }^{204}$ Id. $\$ 119(2)$.

${ }^{205}$ Simons points out that those who own their homes obtain tax-free income at least equal to the cost of housing, because of the failure to tax the imputed value of their home and the allowance of a deduction for interest and taxes. Is it not fair, he suggests, to give a similar advantage to those who, because of the nature of their job, do not have the free 


\section{Evaluation}

It is possible to assume that food or entertainment results in personal satisfaction equal to its cost, because the enjoyment comes from the event itself. Travel, on the other hand, ordinarily provides satisfaction only if you desire to reach the particular destination. While a luxurious suite in a good hotel may provide enjoyment in itself, lodging is close to travel in that the benefit greatly depends on the location and on the ability to spend the day in personal pursuits. Thus, some housing costs must be deductible.

Nevertheless, if the lodging is located at a place the taxpayer is likely to visit on vacation, as when a convention is held at a resort hotel, there is a strong likelihood of personal consumption equal to cost. This could be so even if the taxpayer really does spend the day on business, if the area's attraction is its after-dark activities. Thus, if it were possible to isolate such cases for the purpose of denying any deduction for fares, ${ }^{206}$ a similar denial would be justified for the cost of meals and lodging.

In any event, lodging attributable to days during which business was not actively conducted should not be deductible. While this may overstate consumption when the taxpayer is unavoidably detained for business reasons in a town with no personal attraction, such a rule is a reasonable compromise.

Moreover, while a temporary change in location may indeed prevent the most economical acquisition of housing, it is closer to reality to assume that personal satisfaction from the taxpayer's only dwelling equals cost and to insist, as a condition for the deduction of lodging, that the taxpayer be maintaining another household. This is consistent with the refusal to allow any deduction for meals and lodging while "away from home" to an unmarried traveling salesman who has no permanent place of abode. ${ }^{207}$ Similar reasoning suggests the repeal of section 119 as it relates to housing. However, the exclusion could be retained since it is likely that in many cases the personal satisfaction from institutional housing is greatly below cost. Moreover, probably a great many of the beneficiaries of section 119 are relatively low income people who are not able to take advantage of other tax concessions.

choice to rent or buy. H. Simons, supra note 7, at 123-24. Perhaps so, but it would be better to eliminate the tax advantages of home ownership, as Simons would no doubt agree.

${ }^{208}$ See text accompanying notes $179-82$ supra.

${ }^{207}$ Rosenspan v. United States, 438 F.2d 905 (2d Cir.), cert. denied, 404 U.S. 864 (1971). See Rev. Rul. 73-529, 1973 Inr. Rev. Bull. No. 49, at 9. 
In those cases where a deduction is to be allowed for housing, a strong case can be made for a dollar limitation. ${ }^{208}$ For situations in which the taxpayer does actually obtain personal satisfaction from the entire expenditure, this will restrict the amount of consumption which can be enjoyed tax free. In other instances, even though apart from business a person would not pay anything for the opportunity to spend a night in an ordinary hotel room, it is possible he would spend something for a luxurious suite. This seems especially appropriate if the accommodations far surpass those he has at home. The dollar limit will serve as a means of denying a deduction for that portion of the cost which is more likely to provide personal satisfaction. ${ }^{209}$

\section{H. Entertainment}

\section{The Law}

Prior to 1962, expenditures for entertainment at night clubs, parties or sporting events were deductible, provided the principal purpose of any particular expenditure was business. ${ }^{210}$ Similarly, a portion of depreciation and other costs for maintenance of a yacht or hunting lodge, or a portion of country club dues, was deductible in the ratio of business use to total use of the facility. In part because one's friends are also often one's business associates, and because a subjective test relating to the primary purpose of an expenditure is difficult to administer, the deduction was believed to have been substantially abused. ${ }^{21}$ As previously stated, President Kennedy proposed that, except for limited exceptions, deductions be denied for expenditures on entertainment, for social club dues and for facilities used primarily for entertainment or recreation. ${ }^{212}$ Congress responded only

${ }^{208}$ As noted, President Kennedy in 1961 recommended a maximum limit on deductions for meals and lodging while away from home equal to twice the federal per diem rate. If this had been adopted the limit would now be $\$ 72$ per day. See note 201 supra.

${ }^{209}$ See subsection III 5(b), Job Facilities, supra.

${ }^{210}$ See Robert Lee Henry, 36 T.C. 879 (1961). Other cases do not refer to the principal purpose requirement. See, e.g., Sanitary Farms Dairy, Inc., 25 T.C. 463 (1955), acquiesced in, 1956-2 Cum. Bull. 8. Thus in 1962 the Senate was able to say that "[u]nder present law, where a business purpose, however slight, exists then the entertainment expenses generally are fully deductible if they are 'ordinary and necessary' business expenses." S. ReP., supra note 10, at 25, 1962-3 Cum. Bull. 731.

${ }^{211}$ See U.S. DEP'T OF THE TREasury, Study ON ENTERTAinment Expenses (1961), reprinted as Exhibit $V$ to Statement of Secretary of the Treasury Dillon in Hearings, supra note 8 , at $133-215$.

${ }^{212}$ Hearings, supra note 8, at 282-86. President Kennedy's recommendations regarding food and lodging are described at note 201 supra. He also proposed an allocation of travel expense similar to what is now in effect for foreign travel under $\$ 274$ (c) of the Code. See text accompanying note 165 supra. In addition, he suggested the nondeductibility of business gifts in excess of $\$ 10$ per year per recipient which is now reflected in the $\$ 25$ ceiling on business gifts in $\$ 274(b)$ of the Code. 
by seeking to require the taxpayer to show "a greater degree of proximate relation between the expenditure and his trade or business than is required under present law." 213

The most important reform was the requirement that expenditures for travel, entertainment and gifts be substantiated by adequate records or by other sufficient evidence corroborating the taxpayer's own statement. ${ }^{214}$ No longer were courts to make an approximation when evidence indicated some deductible expenditures were made, but there was no evidence of the amount. In such cases, the entertainment expenses were to be disallowed entirely. The so-called Cohan rule was dead. ${ }^{215}$

Once the expenditure is adequately substantiated, most of what was deductible under prior law will remain so. Cost of entertainment preceding or following a substantial business discussion is generally deductible, ${ }^{216}$ and this will include the expense attributable to the spouse of a person who engaged in the discussion. ${ }^{217}$ If the entertainment is not associated with a business discussion then it must be established that the item was "directly related to . . . the active conduct of the taxpayer's trade or business." 18 The regulations define the meaning of this test in a rambling manner not conducive to easy understanding, but it is fair to say that they generally require a showing that the taxpayer had a specific business benefit in mind which he could reasonably expect to further by discussion or other means, such as product display or publicity, aside from whatever goodwill was developed by showing the other party a good time. Thus, deductions have been denied for boat trips. where the taxpayer did not accompany potential customers, ${ }^{219}$ or where he did not initiate business discussions, preferring the "soft sell."220 The cost of cocktail parties was also disallowed on the ground that the circumstances were not conducive to business discussions. ${ }^{221}$

Operating and maintenance expenditures and depreciation of property used in connection with entertainment are deductible only to the extent use of the facility is "directly related" to the

${ }^{213}$ H.R. REP., supra note 12, at 20, 1962-3 CuM. BuLl. 424. See Revenue Act of 1962 , Pub. L. No. 87-834, § 4, 76 Stat. 960 .

214 INT. Rev. CODE OF 1954, § 274(d).

215 H.R. ReP., supra note 12, at 23, 1962-3 Cum. Bull. 427. See note 13 supra.

${ }^{216}$ INT. REv. Code of 1954, \& 274(a)(1)(A); Treas. Reg. \$ 1.274-2(d) (1963).

217 Treas. Reg. $\$ 1.274-2(d)(2)$ (1963).

218 INT. REv. Code OF 1954, \& 274(a)(1)(A); Treas. Reg. § 1.274-2(c) (1963).

${ }^{219}$ D.A. Foster Trenching Co. v. United States, 473 F.2d 1398 (Ct. Cl. 1973).

${ }^{220}$ Hippodrome Oldsmobile, Inc. v. United States, 474 F.2d 959 (6th Cir. 1973), rev'g

339 F. Supp. 826 (M.D. Tenn. 1972). 1973).

St. Petersburg Bank \& Trust Co. v. United States, 362 F. Supp. 674 (M.D. Fla. 
taxpayer's business, and only if the primary use of the facility during the year was for purposes considered ordinary and necessary under section 162 or 212 . The same rule applies to dues paid to social or athletic organizations. ${ }^{222}$ These stricter tests do not affect expenditures for a particular item of entertainment, such as a meal at a golf club or a particular fishing trip, to which the rules discussed above apply. ${ }^{223}$

\section{Analysis}

Even with the 1962 amendments, present law seems to be directed solely toward a determination of the business purpose of the expenditure. Once the business purpose is found, the possibility of personal benefit is ignored. Section 274 does, however, serve to increase the certainty that significant business benefits exist. For example, if more than one-half of the use of a facility, such as a yacht, is for business purposes, there is some assurance that the taxpayer acquired it in connection with his business.

\section{Evaluation}

As the prior discussion indicates, no deduction should be allowed for expenditures on entertainment. That portion of expenditures on entertainment which is intended as a price rebate to a customer or a kickback to the customer's employees clearly ought to be taxable to the recipient, or in lieu thereof nondeductible. If instead of providing entertainment prices were cut, the customer would have lower costs and higher taxable income. Entertainment is just a means of obtaining a part of that income in a tax-favored way. This causes entertainment to be preferred even if not valued at full cost. If entertainment were not deductible, unless it provided satisfaction equal to cost, it would be more efficient to reduce prices directly, thereby eliminating competitive pressure to provide entertainment.

The analysis is more difficult with respect to the portion of the cost applicable to the taxpayer or its employees, or as to entertainment which is intended to develop and maintain customer goodwill and does not have any direct effect on prices because, for example, it replaces other costs such as advertising. Nevertheless, examination of such entertainment under the guidelines suggested in this Article leads one to a like conclusion. 
The proximate relationship between entertainment and increased income is more difficult to establish than it is with any of the other items previously discussed. Conversely, unlike these other items, entertainment cannot be productive unless someone derives personal satisfaction from it. The business context does not necessarily interfere with personal enjoyment. While it is true that the personal satisfaction of many people would increase if they went to a night club with their spouses rather than with a customer, attendance of spouses would in many cases under present law not prevent the deduction. ${ }^{224}$ Moreover, even if the taxpayer's satisfaction does not equal cost, he may still be indifferent to the effect on potential customers.

For example, suppose that a stock broker desires to go to a football game for which the tickets cost $\$ 15$. If he is in the fifty percent bracket and the cost is deductible, for $\$ 15$ he can buy two tickets. Thus, he might well take a client to the game even if the potential of additional business is slight. Similar arithmetic may cause a high bracket taxpayer to undertake certain activities which he would otherwise not believe to be worth the cost, if inviting a customer along could make the cost deductible without appreciably increasing the expense. For example, a chartered yacht for a day may cost $\$ 1,000$, while the taxpayer is only willing to spend $\$ 600$. If the cost is deductible, the out-of-pocket expenditure will be $\$ 500$. In this case, the fact that the taxpayer does not obtain $\$ 1,000$ of personal satisfaction does not show business must have been a motivating factor.

Finally, as previously discussed, it seems reasonable to resolve doubt in favor of risking overstatement of income rather than accepting the serious understatement that occurs from assuming no personal satisfaction from business entertainment. ${ }^{25}$ Expense account living, encouraged by absence of tax, undoubtedly affects the morale of those who are unable to share in the benefits. The apparent absence of any serious effects from the limitations on deductibility imposed in 1962 may indicate that further restrictions will not greatly endanger business efficiency. In fact, efficiency may be increased by less.reliance on entertainment. Even if total disallowance seems too drastic a step, the fact that some personal benefit undoubtedly exists should be acknowledged by denying a deduction for some portion of all entertainment expenditures. The deductible part would reflect the assumed cost in excess of satisfaction.

\footnotetext{
${ }^{224}$ See Rev. Rul. 63-144, 1963-2Cum. Bull. 129, 134-35.

${ }^{225}$ See text accompanying notes 67-69 supra.
} 


\section{Conclusion}

An examination of existing law in light of the principle that deductions should be limited to the excess of cost over personal satisfaction has led to the following recommendations:

Education: Allow amortization of the cost of professional and certain other postgraduate education and vocational training after high school.

Job seeking: Allow a deduction for, or amortization of, jobseeking costs not involving travel or education.

Clothing: No change in present law.

Office in the home: Deny a deduction unless the principal purpose of acquiring the space is business. Unless personal use is insignificant; the deduction when allowable should be based upon the ratio of business use to total hours in the period.

Travel: Extend allocation rule of section 274(c) of the Code to all travel, including the cost of seeking employment. The deduction permitted would be in the ratio of time spent on business to total time on the trip. Attention should be devoted to an effort to limit the portion of the trip allocated to business to the actual time so spent. Consideration should be given to whether a deduction can be fully denied for certain trips, e.g., conventions at vacation spots, which appear to result in personal satisfaction equal to cost. If so, meals and lodging on such occasions also should not be deductible.

Food: Deny all deductions for the cost of food. If this is not acceptable, do not allow a deduction for food consumed in the home or for lunches wherever they take place. Place a low dollar limit on deductions for breakfast and dinner. The exclusion under section 119 for meals provided for the convenience of the employer should be consistent with the dollar limit.

Lodging: Deny a deduction unless lodging duplicates housing otherwise available and in all cases for days not spent on business. A dollar limit should apply.

Entertainment: Deny any deduction.

Corporations and other business taxpayers would be allowed to deduct. disallowed items if income is allocated to individuals designated by the filing of information returns.

Obviously, most of what has been proposed would require legislation-because of the clear indications of congressional satisfaction with some existing rules, and because it seems impossible to impose dollar limits without statutory guidelines. Nevertheless, in some areas it is possible for the courts and the 
Service without action by Congress to modify the law in accordance with the principle of allowing business expenditures to be deductible except to the extent personal satisfaction is obtained. The recent loosening with respect to employment agency fees may indicate a general liberalization in the whole area of expenses preparatory to working. Allowing the amortization of certain educational expenses seems within the province of the courts, since there is no conflicting legislation or well-considered judicial precedent. Disallowance of the cost of meals and lodging to a taxpayer living in a private residence with his family, temporarily away from his permanent business location, may result from the Second Circuit decision in Rosenspan ${ }^{226}$ which suggests that such a taxpayer is not "away from home." A tightening of the rules with respect to a deduction for a home office also seems within the realm of the courts or the Service, since neither they nor Congress have really faced the issues involved in this deduction. For the big task, travel and entertainment, action by Congress is needed, and it is time it got on with the job. (1971).

${ }^{226}$ Rosenspan v. United States, 438 F.2d 905 (2d Cir.), cert. denied, 404 U.S. 864 